AROUEOLOGía Y SociedAD

№ 25, 2012: $353-374$

ISSN: 0254-8062

RECIBIDO:JULIO DE 2012

ACEPTADO: OCTUBRE DE 2012

\title{
"DEJANDO HABLAR". LOS ESTUDIOS ANDINOS COLONIALES (SIGLOS XVI D.C. AL XVIII D.C.) SEGÚN LA VERSIÓN DEL OTRO PROTAGONISTA: LA VOZ INDÍGENA DESDE LOS VASOS DE MADERA PINTADOS TIPO LLIMPISCCAQUERO
}

\author{
MANUEL LIZÁRRAGA IBÁÑEZ \\ Magíster en Estudios LATINOAMERICANOS. UNIVERSIDAD DE CHILE \\ lizarraga.ma@pucp.edu.pe
}

\section{RESUMEN}

Los cambios en el orden mundial tienen resonancia al interior del ámbito académico. Así luego de la pérdida de la hegemonía universal de Occidente y con ella, la caída de su matriz de conocimiento euro-céntrico: científica y racional (moderna según Immanuel Kant); se iniciaron estudios sociales y humanos que pretendían buscar, principalmente, las otras voces que se encontraban al margen -silenciadas- por mentada matriz de conocimiento occidental (como la racionalidad andina colonial, por ejemplo). En ese sentido, el presente ensayo intentará recuperar las voces de las sociedades andinas coloniales a través del estudio de sus propios sistemas de soportes de origen prehispánico («etno-soportes») que continuaron circulando -pero reconfigurados- al interior del contexto colonial; en especial: los vasos de madera pintados bajo relieve tipo llimpisccaquero (siglos XVI d.C. al XVIII d.C.).

El ensayo concluye que, a través del estudio del lenguaje visual puesto en estos queros coloniales polícromos (llimpisccaqueros), los investigadores actuales podemos llegar a obtener discursividades y opiniones indígenas propias acerca de la realidad colonial que, en cierta medida, se encontraban ausentes o minimizadas en los registros escritos.

PALABRAS ClAVE: Queros coloniales (siglos XVI d.C. al XVIII d.C.), sistemas de soporte de comunicación y memoria, lenguajes visuales andinos coloniales.

\section{Abstract}

The changes in the world wide order have resonance to the interior of the academic area. Thus after the loss of the universal hegemony of West and with this one, the fall of his euro-centric knowledge matrix: scientific and rational (modern according to Immanuel Kant); there began social and human studies that were trying to search, principally, the other voices that they were finding to the margin -silenced- by mentioned western knowledge matrix (as the Andean colonial rationality, for example). In this sense, the 
present essay will try to recover the voices of the Andean colonial societies across the study of his pre-Hispanic support systems («ethno-support») that they continued circulating -but reconfigured-inside colonial context; especially: the low relief painted wooden cups type llimpisccaquero (16th to 18th Century).

The essay concludes that, across the study of the visual language put in the colonial polychromatic quero wooden cups (llimpisccaqueros), the actual investigators we can obtain indigenous narratives and opinions about colonial reality that, up to a point, are absent or minimized in the written records.

KEYwords: Colonial quero wooden cups (16th-18th Century), communication and memory support systems, Andean colonial visual languages.

The times they are a-changin'.

Bob Dylan (1964)

Los cambios en el orden mundial afectan en las preguntas y desafíos de los estudios sociales, esto es: influyen en los temas que se van a discutir en el futuro inmediato (Robotham 1997). A raíz de esta resonancia al interior del ámbito escolástico, cada nueva coyuntura de carácter mundial ofrece, por lo general a la Academia, un cambio hermenéutico en la manera de entender sus problemas; a saber: un nuevo protocolo para acercarnos al objeto tradicional de estudio, de leerlo e interpretarlo -«de hablar de ellos» según Weeks (1993)-; e incluso estimula y alienta, con ánimos de obtener una mayor fidelidad informativa, buscar nuevos y alternativos sistemas de soportes para su estudio (no tradicionales ni de uso convencional para la Academia).

Por tanto y para nuestro mundo contemporáneo: luego de la caída del Muro de Berlín (1989), el triunfo del neoliberalismo -a escala global- y la aparición de «nuevas modernidades alternativas» al mundo occidental (como China y el Sudeste Asiático); surgieron distintos enfoques sociales que intentaron explicar, e interpretar, el reciente contexto internacional (uno ya sin hegemonías globales y con la presencia -ya no subalterna- de diferentes sistemas de pensamiento (epistemes; cf. más adelante) distintos a la matriz científica, racional, moderna y hegemónica de Occidente). Debido a ello, aparecieron propuestas investigativas que rechazaron las posturas universales, homogéneas y centralistas («la física social») para asumir en cambio, un estudio más interpretativo, de «conocimiento local» de carácter polifónico y multiautoral (es decir: uno que responda a muchas voces y lugares sociales; tal como lo propone la «Antropología Interpretativa» planteada por Clifford Geertz (1994)). En efecto, la pérdida de la hegemonía universal de Occidente -y con ella, de su episteme $e^{1}$ eurocéntrica basada en su racionalidad empirista y científica según Habermas (1989)- originó en la Academia, el interés por rescatar las otras voces que se encontraban al margen de mentada racionalidad europea y moderna (como la del Islam o de la cultura andina, por citar algunos ejemplos) impulsando, como sugiere León-Portilla (1961: IX): a «estudiar el problema a la inversa, es decir preguntarnos: ¿qué pensaron -por ejemplo- las sociedades andinas del siglo XVI al ver llegar a sus costas y pueblos a los primeros descubridores, y posteriores, conquistadores europeos?».

Atendiendo estos nuevos desafíos, el objetivo central del presente ensayo será investigar: ¿dónde se encuentran «las voces andinas coloniales» (su opinión no hegemonizada por el discurso hispano letrado) ante el encuentro/choque con los conquistadores españoles (es decir: su versión de los hechos)?; esto es: ¿bajo qué materialidades y lenguajes propios buscar? De este modo, y luego de haberla identificado, (esperamos) reconocer el tipo de temáticas y enunciaciones de estas voces nativas («sus lecturas propias») ante las prácticas colonizadoras hispanas; en especial: caracterizar la reacción de los artesanos andinos coloniales ante los impulsos visuales venidos con los conquistadores españoles del siglo XVI.

1 Del griego «saber» o «conocimiento». Sistema de pensamiento. Estructuras y formas de un conocimiento razonable y pensado compartido por un grupo social. 
Para llegar a resolver esto asumiremos, a modo de hipótesis, la existencia de un conjunto nativo de sistemas de soportes ${ }^{2}$ que desde el siglo XVI en adelante plasmaron las "voces andinas coloniales», a saber: materialidades sensibles y comunicativas de origen prehispánico («etno-soportes») con lenguajes diferentes a la escritura alfabética y que siguieron circulando, pero reconfigurados, al interior del contexto colonial; como por ejemplo: la visualidad expuesta en los «vasos de palo» pintados -«labrados de colores» ${ }^{3}$ - con la técnica bajo relieve conocida como "laca incrustada» ${ }^{4}$ (llimpisccaqueros al decir de González Holguín (1952 [1608]: 213) pues, según el mismo compilador, eran vasos pintados tipo «llimppicuna: [de] todas maneras de colores del lacre con que pintan vasos de madera. Todos los colores de pintar» (op. cit. 213). (Fig. 1). Entonces e impulsados por los nuevos retos planteados a la Academia a raíz de los cambios en el orden mundial, postulamos que: a través del estudio de estos «etno-soportes» (para nuestro caso específico, de los queros coloniales polícromos tipo llimpisccaquero), obtendremos la respuesta y reacomodo visual indígena ante las prácticas colonizadoras de la representación hispana. Un testimonio indispensable, e inédito, para la construcción de un relato polifónico y multiautoral de los «Estudios Andinos Coloniales (siglos XVI al XVIII)».

\section{«DEJANDO HABLAR»... AL RESCATE DE LA EPISTEME ANDINA COLONIAL}

Al decir de algunos investigadores (Wachtel 1976; León-Portilla 1961 para el caso americano), la historiografía occidental ${ }^{5}$ de buena parte del siglo XX estuvo relacionada con la justificación ideológica de la expansión y hegemonía de los «hombres blancos y racionales» sobre el mundo pues, escribir historia, siempre ha tenido una connotación ideológica que sólo ha servido a intereses particulares de algunos grupos específicos, en especial a las élites dominantes o, siguiendo a Foucault (ver Powell y Azrini 2003), de los actores sociales poseedores de los «serious spreech acts» ${ }^{6}$; anulando con dicha posición social privilegiada, la participación de los demás grupos implicados y considerados por ellos como subalternos (Appleby et al. 1999). Es por ello que, según mentada historiografía, los temas y actores de la Historia Universal -los grandes personajes- se encuentran siempre en relación con las sociedades europeas, ignorando la participación y reacción de aquellas sociedades no-europeas (para nuestro tema de estudio: de las sociedades andinas coloniales). Sin embargo, fue recién con la caída de dicha supremacía intelectual -autodeclarada por supuesto- y con el auge de los movimientos postcoloniales (Robotham 1997) que, la historiografía occidental «tomo conciencia de que también exis-

2 Sistemas de registro (de índole estatal como regional) que operaron como soportes de información religiosa y de temáticas vinculadas al poder, identidad y memoria social ( Martínez Cereceda 2011). Unidades discretas y sensibles portadoras de significación para las sociedades receptoras. Sistemas semióticos con particularidades y estéticas propias (Greimas 1971). No confundir con support (sólo el soporte material).

3 González Holguín (1952 [1608]: 213).

4 La técnica de «laca incrustada» es un método de aplicación de pintura en bajo relieve. Mediante análisis químicos, Kaplan et al. (1999: 33-34) determinan que «la pintura es una mezcla compleja de partículas de pigmentos minerales y/o colorantes orgánicos, con una resina natural como medio aglutinante»; donde los pigmentos utilizados provienen del índigo, cobre, plomo, bermellón, sulfuro de arsénico, oropimente y carbón. Siguiendo con dichos resultados, el medio aglutinante -es decir, el material que une a los colorantes entre sí y éstos a la madera- «es un exudado de la planta Elaeagia pastoensis Mora, mezclado con un aceite semisecante. Este exudado se conoce con el nombre común de mopa mopa».

5 Registro escritural alfabético (bibliográfico y crítico) de los estudios sobre el pasado, sus fuentes y autores de la civilización occidental; entendida esta última, como el conjunto de sociedades influidas por las civilizaciones greco-romanas, el cristianismo, el Renacimiento y la Ilustración; por tanto, conjunto de culturas con un fuerte euro-centrismo.

6 Discursos que organizan las conductas de los hombres ya que imponen esquemas mentales, clasificaciones -estereotipos- para determinados fines e incluso, según los contextos de uso, pueden éstos cambiar las actitudes socio-mentales hacia una idea preconcebida: por lo que un discurso autorizado -según Foucault- es un control efectivo de voluntades y racionalidades de las personas (Powell y Azrini 2003: 5). 


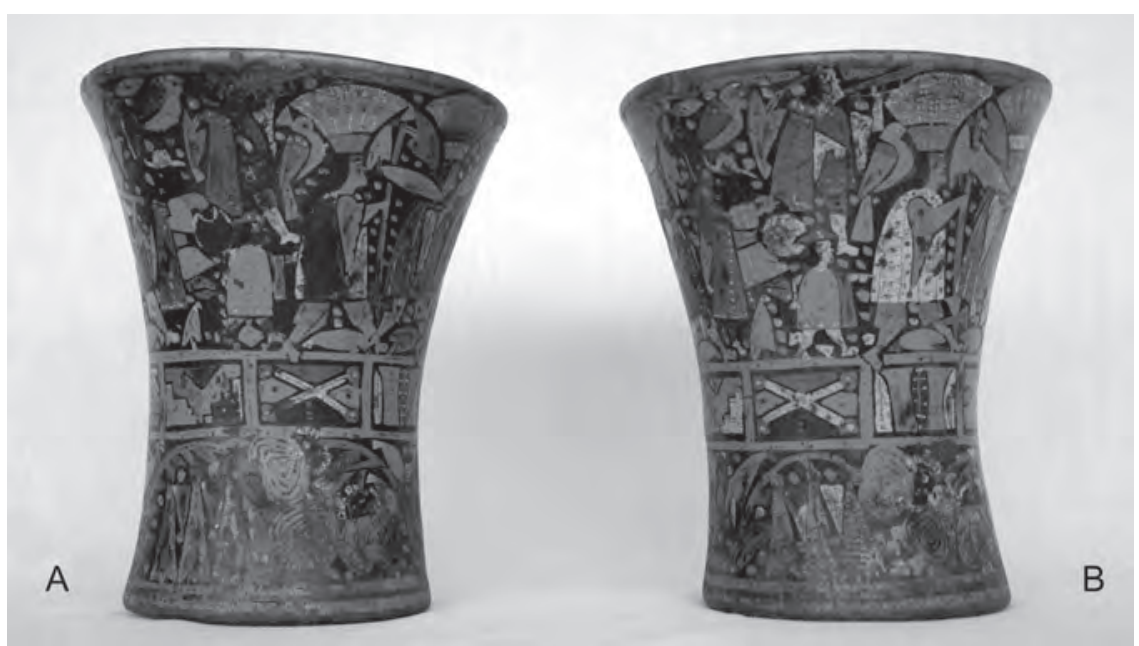

Figura 1. Llispisccaqueros andinos coloniales (siglo XVII). «Vasos de palo» figurativos, pintados bajo relieve con la técnica "laca incrustada» y organizados, estos dos ejemplares, en tres campos horizontales (piezas R1162 (A) y R1161 (B), colección Museo de Etnografía y Folklore (MUSEF) de la ciudad de La Paz-Bolivia, fuente Proyecto FONDECYT 1090110). Es la disposición de campos más común entre este tipo de queros coloniales pero no es la única pues, Verena Liebscher (1986) identifica otras más.

ten otras sociedades, es decir, que tienen su historia particular y de que ésta no sigue necesariamente las huellas del modelo europeo» (Wachtel 1976: 23).

En ese sentido y para los Andes, la periodización occidental -Estados Unidos y West Europe principalmente- ha entendido el encuentro entre las huestes de Pizarro y las sociedades indígenas del siglo XVI como un proceso de «Conquista» (Wachtel 1976), dejando en claro, con dicha clasificación, la supremacía del hombre blanco-europeo sobre la población india (sobre los pueblos bárbaros recién descubiertos por los «ojos imperiales»). Por tanto, y siguiendo a la historiografía occidental, lo más importante al momento de escribir historia andina colonial sería escuchar la perspectiva de los colonizadores europeos a través de su propio registro escritural y letrado. Entonces a raíz de esta selección de fuentes y lenguajes, se instala -en la historiografía sudamericana- una jerarquía documentaria de la letra alfabética y eurocéntrica sobre la oralidad y pictografía nativa (Cornejo Polar 2003). Sin embargo y tal como señalamos líneas arriba, entre los siglos XVI y XVIII se ha identificado -en los Andes coloniales- un conjunto de sistemas de soportes (entre estatales y regionales) con lenguajes diferentes a los de la escritura alfabética (como los visuales) expuestos por ejemplo: en los «vasos de palo» pintados tipo quero polícromo, textiles, arte rupestre y teatralidades (entre los más representativos); y por donde circulaba, lo que podríamos denominar: las «voces andinas coloniales» ( Martínez Cereceda 2011, $2008 \mathrm{~ms}$ ).

Esto último indicaría que, a pesar de la existencia de un «proyecto colonial» interesado en aplicar una desestructuración y clausura total incásica (las reformas toledanas: 1568-1581 y Concilios Limenses de 1551-1552 y 1567-1568 como las medidas más radicales) las voces indígenas no se silenciaron sino más bien, fueron rearticuladas -desde temprano- tomando en consideración, a raíz de su permeabilidad con la «ciudad letrada» hispanoamericana y el impacto del «proyecto visual colonial»":

7 Proyecto preocupado en disciplinar el ojo indígena a través de la introducción de nuevas formas gráficas que formalmente signifiquen por mimesis y de su realidad efectiva: la pintasca (revísese nota 9). Proyecto visual colonial que según Catherine Julien (1999: 63), trataba «the introduction of European canons of representational art in the Andes» para «hacerlos pintar con la curiosidad que tienen los de allá» (Iwasaki Cauti 1986: 67). 


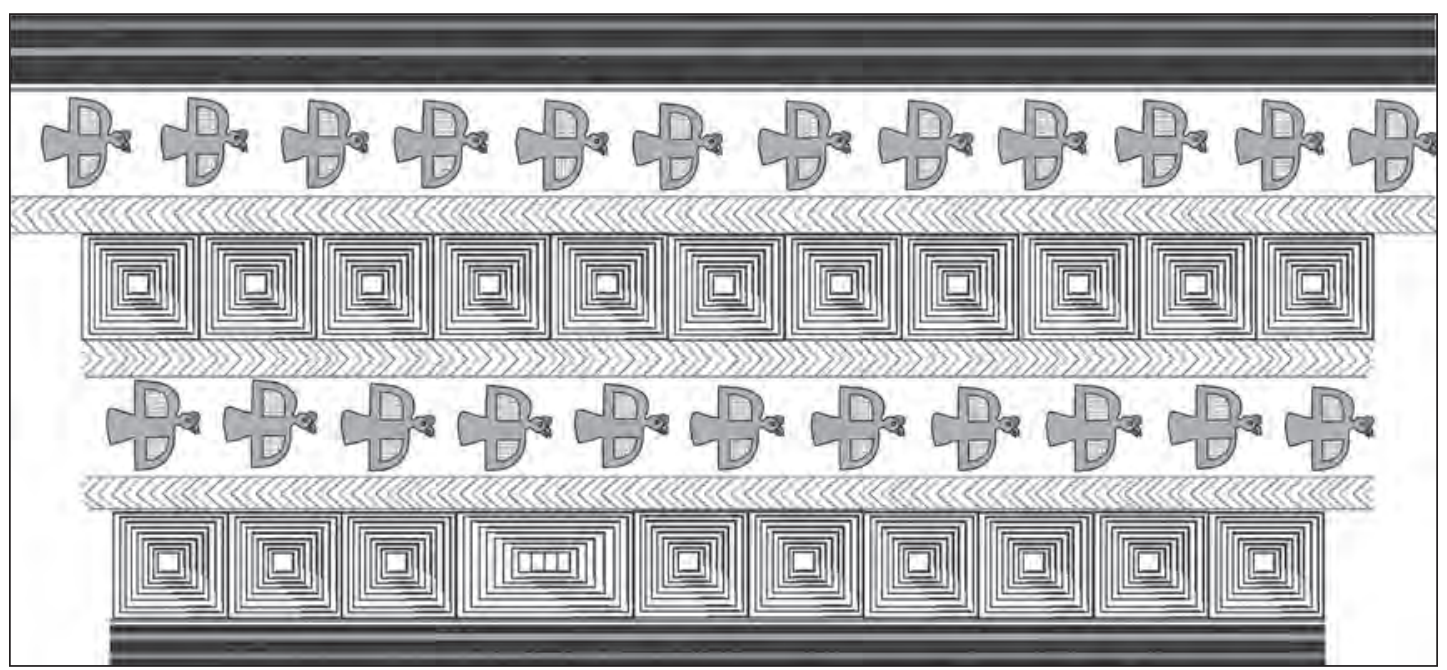

Figura 2. «Giro pictórico» de los queros de la transición (ca. 1530 hasta el último tercio del siglo XVI) hacia formas con mayor policromía y trato más figurativo que sus pares incaicos (pieza MOMAC 209, colección Museo Inka de la UNSAAC. Fuente: Proyecto FONDECYT 1090110. Dibujo: C. Yáñez).

las convenciones figurativas y representacionales del registro pictórico hispano renacentista (tal como sucedió, por ejemplo, con el giro pictórico dado por los llamados «queros de la transición» (Figs. 2 y 4b): «vasos de palo» inciso-pintados del último tercio del siglo XVI d.C. que muestran una mayor policromía y trato más figurativo que sus pares incaicos caracterizados por tener, estos últimos, significantes geométricos abstractos lineales (Fig, 3) Para más detalles, revisar: Rowe 1961, 2003 y Flores Ochoa et al. 1998). Entonces tenemos un sistema de soporte y registro de origen prehispánico (el quero) que, a raíz de la imposición y expansión del «proyecto visual colonial», capturó -de manera consciente y rápida (casi inmediata)- los estímulos figurativos de la visualidad hispana renacentista y manierista de la pintasca (aquellos que les causaba curiosidad).

Así y para el presente ensayo, se entiende la apropiación pictórica andina de las convenciones visuales europeas (especialmente de la pintasca ${ }^{8}$ renacentista y manierista mediterránea) como un proceso consciente e instrumental (de mecánicas propias) a través del cual, elementos y conceptos representacionales ajenos a las sociedades indígenas coloniales fueron asimilados y convertidos como suyos («traducidos visualmente»), por parte de los mismos artesanos nativos contemporáneos (los querocamayocs). Es decir y tal como se visualiza en los queros de la transición (regresar a Fig. 2 e ir a 4b),

8 Pintura europea en términos del siglo XVI d.C. (Cummins 1998b) como aquellas expuestas, por ejemplo, en el cuadro «Adoración de los pastores» de Pieter Aersten (Catálogo del MNA 2005: 27) o «La Virgen con el Niño» de Jan Metsys (Mesa y Gisbert 1962: fig. 3). Estilo retórico usado por el informante nativo Cristóbal Choque Casa -indígena cristianizado y mediado por el lenguaje de las artes pictoriales de la Europa del siglo XVII- para denunciar ante Fernando de Ávila en 1608, en el pueblo de Huarochirí, aquellas figuras locales (de sus ídolos) que no obedecían las reglas visuales de los españoles (de las imágenes católicas) puesto que las primeras, no estaban basadas en modelos iconogáficos reales conocidos por el poder eclesial castellano. Siguiendo a Tom Cummins (1998b: 32), con el uso del término pintasca «Don Cristóbal va más allá de la clasificación ontológica andina de la imagen para verla como una pintura en términos europeos [del siglo XVI d.c.]»; reafirmando con dicho término, la identidad europea de la imagen. Entones, se trata de aquellas representaciones (como la figura ecuestre de la pintura manierista) que según Wölfflin (1961), se caracterizaban por ser imágenes táctiles, a saber: figuras que trataban de capturar -por medio del linealismo- las formas según sus proporciones sensoriales «como si se pudiesen tocar». Debido a ello, fueron pinturas que se preocuparon por representar «las cosas como son», es decir: de significado mimético. 


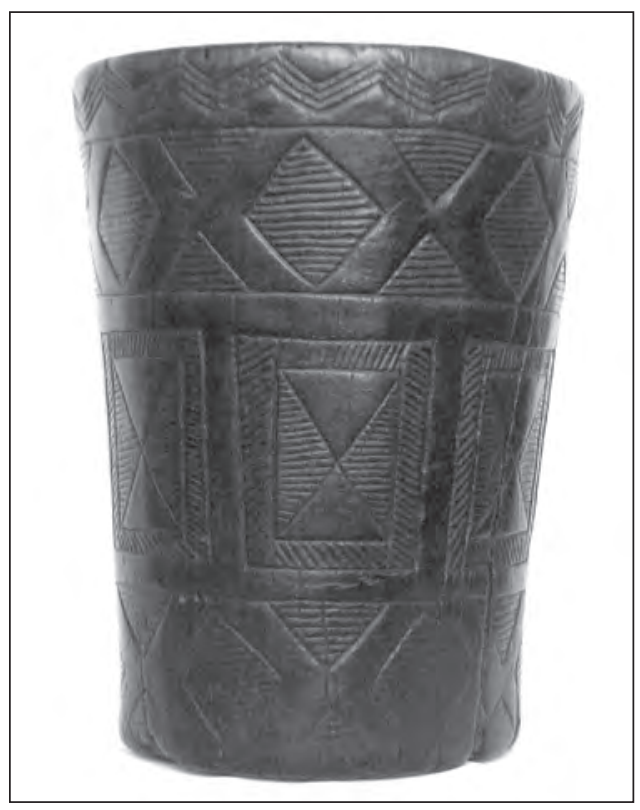

Figura 3. Quero incaico de madera (1470-1533 d.C.) con decoración geométrica abstracta lineal incisa sobre fondo de madera natural (pieza IV-2.3-0593. Colección Museo de Arte de Lima (MALI). Fuente Proyecto FONDECYT 1090110).

ocurrió una rápida apropiación de un código visual distinto -el renacentista y cristiano- para traducirlo visualmente a otro más propio -el andino colonial-. De este modo (y como parte de este proceso de captura), los querocamayocs lograron dominar la visualidad hispana del Cinquecento en adelante; pudiendo con ello, reconfigurar algunas de sus formas artísticas muy usadas (como las criaturas fabulosas del «Bestiario Medieval» europeo $\mathrm{y}$ otros significantes visuales de origen y estilo antiguo) y resemantizar ${ }^{9}$, aunque no totalmente, algunos contenidos mediterráneos de las mismas. Entonces una apropiación visual andina colonial que facilitó la circulación contemporánea de sus «vasos de palo» pintados (llimpisccaqueros) pues, a través de la captura de dichos cánones artísticos europeos, este sistema de soporte de origen precolombino (junto a otros, como los textiles toccapuccumbi por ejemplo) fueron reconfigurados pudiendo así sortear la persecución civil y eclesial colonial ya que, al decir de los primeros curas extirpadores (como Cristóbal de Albornoz ca. 1582), los queros incas con sus dibujos abstractos lineales (por no ser miméticos) eran considerados como objetos idolátricos que «conducían al engaño» ${ }^{10}$. Por tanto de esta forma (reconfigurada), los «etno-soportes» (como los queros) tuvieron la oportunidad de continuar operando dentro de este nuevo y extraño escenario visual colonial.

Debido a que el presente ensayo pretende buscar, y rescatar, el antiguo testimonio dejado por las sociedades andinas coloniales (entre ellas la incásica) frente al encuentro/choque con la racionalidad colonizadora hispana; se indagará por tanto: ¿qué tipo de enunciaciones visuales nativas surgieron como respuesta al arribo hispano a «las Indias»? («pasar al otro lado del escenario» según Nathan Wachtel); para así obtener, por medio de sus testimonios figurativos, la «visión de los vencidos». Para llegar ello la investigación buscará, primero: ¿en qué materialidades locales -sistema de soporte- quedó plasmada las «voces andinas coloniales»?, para después, y luego de haberlas rescatado (las «(sub) versiones de los vencidos»), proceder a problematizar éstas con el discurso euro-céntrico creado en torno a la colonización del Nuevo Mundo (Bernal 1993); como aquél que asumía: a «los indios como gente bárbara, idólatras entregados a la antropofagia y a la sodomía» (León-Portilla 1961: VIII-IX). Es decir, cuestionar la historiografía occidental que considera la incapacidad de las sociedades andinas coloniales para dar su opinión, de reacomodarse y reaccionar, frente a la nueva coyuntura colonial acaecida en su entorno geográfico y social de ese entonces. Producciones que como veremos en el transcurso del presente ensayo, fueron falsas.

En ese sentido y con la intención de elaborar un estudio polifónico y multiautoral de la colonización española en América, "haremos hablar» a la episteme andina colonial mediante el análisis de sus propios sistemas de comunicación (como los queros, textiles, el arte rupestre, los jarawis ${ }^{11}$, entre

9 Con sellos y lecturas propias (andinas coloniales).

10 Según Baxandall (2000).

11 «Bailes de memoria». 


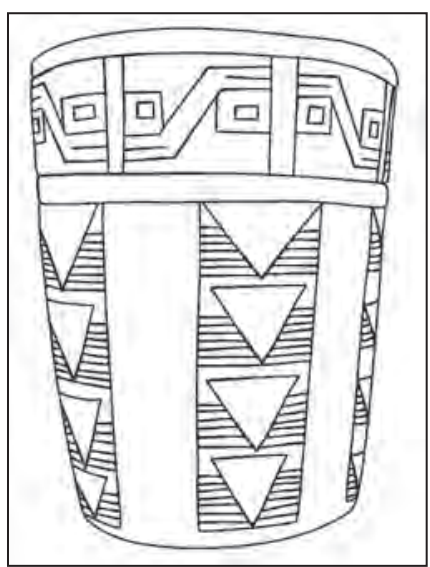

Figura 4a. Quero incaico-cusqueño (1470-1533 d.C.) decorado con diseños abstractos geométricos lineales incisos: tocapu tipo llave en el borde del vaso. (Pieza MO 0095. Colección del Museo Nacional de Arqueología, Antropología e Historia del Perú. Dibujo: C. Yánez, color de fondo madera natural. Fuente: Proyecto FONDECYT 1090110).

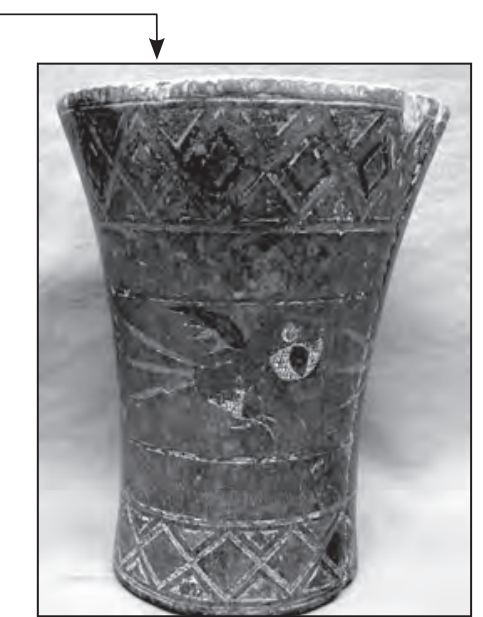

Figura 4b. Giro decorativo y figurativo en los queros de la transición (ca. 1530 - hasta el último tercio del siglo XVI). (Pieza MO 10393. Colección del Museo Nacional de Arqueología, Antropología e Historia del Perú. Fuente Proyecto FONDECYT 1090110).

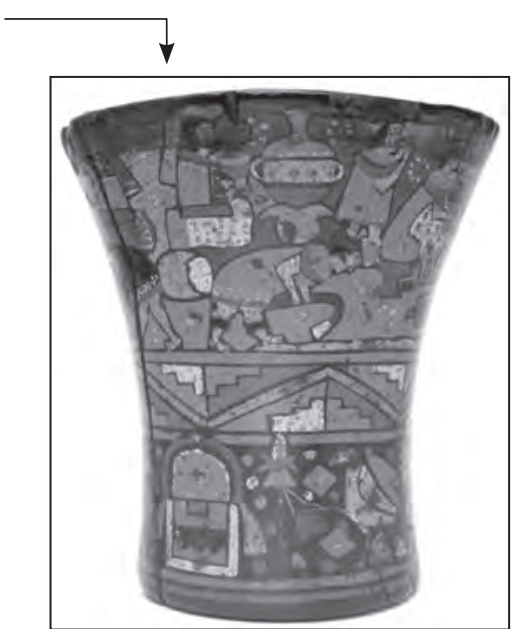

Figura 4c. Quero colonial policromo y figurativo (siglo XVII). Escena "Encuentro incas con collas». (Pieza MAM 7523. Colección del Museo de América de Madrid. Fuente: Proyecto FONDECYT 1090110).

Figura 4. Reconfiguración pictórica del quero (sistema de soporte de origen prehispánico); a raíz del impacto de la visualidad hispano renacentista, europea manierista y cristiana (desde fines del siglo XVI d.C. en adelante). Nótese los cambios iconográficos y temáticos en las decoraciones de estos "vasos de palo», a saber: de imágenes abstractas incas a otras narrativas figurativas coloniales ("from abstraction to narration» según Thomas Cummins).

otros); los cuales, si bien de origen precolombino y por tanto con lenguajes diferentes a la escritura alfabética (como los visuales), tuvieron vigencia colonial al margen de la «ciudad letrada». Confiamos que a través del estudio de estos «etno-soportes» (como los llimpisccaqueros), obtendremos discursos más fieles a las «voces andinas coloniales» y elaborar así, una historiografía andino colonial más completa que aquél basado únicamente en el análisis de las (manoseadas) fuentes escritas.

Los queros fueron «vasos de palo» que plasmaron enunciaciones, memorias y relatos propios a las comunidades indígenas (en especial de la élite) a través de su exposición visual y pública (en los «banquetes políticos $»^{12}$ por ejemplo) y por los significantes ahí dibujados: geométricos abstractos lineales ${ }^{13}$ durante el Tahuantinsuyo (Figs. 3 y 4 a) y de trato más figurativo, realista y mimético ${ }^{14}$ para el período colonial (Cummins 1988. Ver Fig. 4c). Debido a esta capacidad de registro y comunicación, y siguiendo

12 Manera tradicional de compartir la comida y bebida entre el estado Inca y las comunidades andinas locales subalternas. Probablemente utilizado para cimentar las lealtades y ayudar entre los comensales y motivar, ademas, la colaboración político y militar entre ambos (Dillehay 2003).

13 Entendida aquí -siguiendo la historiografía artística y etnohistórica del tema ( Martínez Cereceda, comunicación personal, 2009; Cummins 1988)- como, aquellos significantes sin referentes reales conocidos (tanto para las conquistadores españoles del siglo XVI como para la historia del arte actual); a modo de ejemplo: la decoración geométrica incisa de los queros incaicos (llamados tocapus por las sociedades andinas).

14 Arte imitativo o cercano a la realidad. Basado en ideas neo-platónicas que consideraban lo semejante como la mejor manera de acercarse a lo verdadero. 
a Hill Boone (1994: 3), los queros fueron un sistema de soporte indígena que tuvo cualidades de «art and writing»; esto es: un arte visual que no puede estar desligado de su principio comunicativo. Por tanto, y siguiendo dicha interpretación, el presente ensayo intentará penetrar en el lenguaje icónico -las escenas narrativas y figurativas- de los queros coloniales polícromos pintados con la técnica de «laca incrustada» (llimpisccaqueros de los siglos XVI-XVIII) para así indagar, el impacto representacional europeo-cristiano en las expresiones visuales nativas, en especial: la captura, apropiación y resemantización indígena de sus mismas y convenciones figurativas.

Con dichos estudios -pensamos-, los investigadores sociales tendremos mejores herramientas para comprender la relación dominador/dominado acaecida en dicha época además de construir, un relato sobre la colonización andina mucho más completo (polifónico y multiautoral). Como es de suponer, el presente ensayo está consciente que tanto los discursos (icónicos, textuales y orales) logrados por las sociedades andinas coloniales como aquellos realizados por los colonizadores españoles tendrán puntos de desacuerdo -diferencias (como resaltar, para el caso de las formas de enunciación nativas coloniales (el lenguaje visual de los queros), la estructura «femenino-masculino» ( Martínez Cereceda 2011). Ir a nuestra Figura 7 para visualizar rol de Ñusta Chañan Curi Coca en el ciclo mítico «Guerra incas contra chancas»)- los cuales sin embargo, nos ayudaran a profundizar -por sus versiones de los hechos- en el tipo de encuentro/choque ocurrido entre España y las sociedades andinas coloniales de los siglos XVI d.C. en adelante puesto que, la iconografía inscrita en los queros y las interpretaciones en torno a ellas otorgaran, de hecho, información ausente o minimizada en las narrativas históricas construidas únicamente a partir de registros escriturales.

\section{PASANDO AL «OTRO LADO DEL ESPEJO»:} LOS SISTEMAS DE SOPORTE ANDINOS COLONIALES

«El virreinato fue la continuación del imperio» John Rowe (El movimiento nacional inca del siglo XVIII, 1976: 18)

¿Dónde quedó plasmado el impacto -su opinión- de las sociedades incásicas ante el arribo hispano del siglo XVI?, ¿por dónde buscar? Fueron algunas de las interrogantes que motivaron mi interés acerca de estudiar el período colonial temprano. Para responderlas, asumiremos que el período colonial temprano no significó una clausura inmediata de las prácticas andinas ya que el Incario no acabó en absoluto al momento de la conquista española ni en la posterior formación del Virreinato del Perú (Rowe 1976). Es más, al decir de Frank Salomon (1994), la sociedad colonial temprana heredó -para organizar el naciente aparato virreinal- muchos roles e instituciones de la sociedad fragmentada inca, a saber: el reconocimiento a la nobleza inca y sus respectivas autoridades locales (los curacas). En consecuencia de ello, dichos personajes -a diferencia de los indios ordinarios- gozaron de privilegios legales y económicos; como por ejemplo: participar en la administración colonial (Rowe 1976).

Debido al respeto inicial hispano de las lealtades incásicas y tal como se ha sugerido líneas arriba, es muy probable que los mismos sistemas de soportes, registro y memoria utilizados en la época prehispánica -en especial: aquellos que guardaban los discursos y «arte de curacas», como queros, varas textiles, quipus y tablas ( Martínez Cereceda 2011; Lizárraga 2009 y Stastny 1993)- hayan continuado circulando, en los primeros años de la colonia, pero no de forma "pura» (Cummins 1998a) sino con ciertas transformaciones, readecuaciones y reemplazos producto del impacto visual y representacional de los cánones artísticos hispano renacentistas y manieristas expuestos principalmente en la pintasca; los cuales, no sólo afectaron en las formas, temáticas y lenguajes de enunciación de éstos sino también sus respectivos espacios de circulación.

Así los «vasos de palo» sufrieron -a partir de la segunda mitad del siglo XVI d.C., en adelante- cambios formales en su iconografía pues: de una decoración inca imperial basada, en las piezas de madera, 
en significantes geométricos abstractos lineales incisos (no-figurativos) así como en diseños antropomorfos esquemáticos también incisos (vg. manos y rostros) se pasó, previa experimentación con los queros de la transición (ultimo tercio del siglo XVI), a queros coloniales con diseños más figurativos, realistas y polícromos que sus pares incásicos («from abstraction to narration» según Cummins 1988. Fig. 4). Es por ello que desde fines del siglo XVI en adelante, aparecieron queros con representaciones estilizadas y coloreadas (con rojo, amarillo, negro, verde, café y azul; Kaplan et al. 1999) de seres humanos, plantas, animales, edificios, objetos insertas dentro de acciones (como danzas, banquetes, guerras, arriería, etc.) y ordenadas en escenas narrativas complejas (tal como aparece en la escena «Encuentro entre incas y collas -también conocida como Incari-Collari o Brindis de la fertilidad-». Fig. 5). Es decir: de imágenes abstractas a escenas narrativas figurativas; y con ellas, siguiendo (no del todo) la ontología de la pintasca europea del Cinquencento: hacia la imagen como representación y figuración de la realidad.

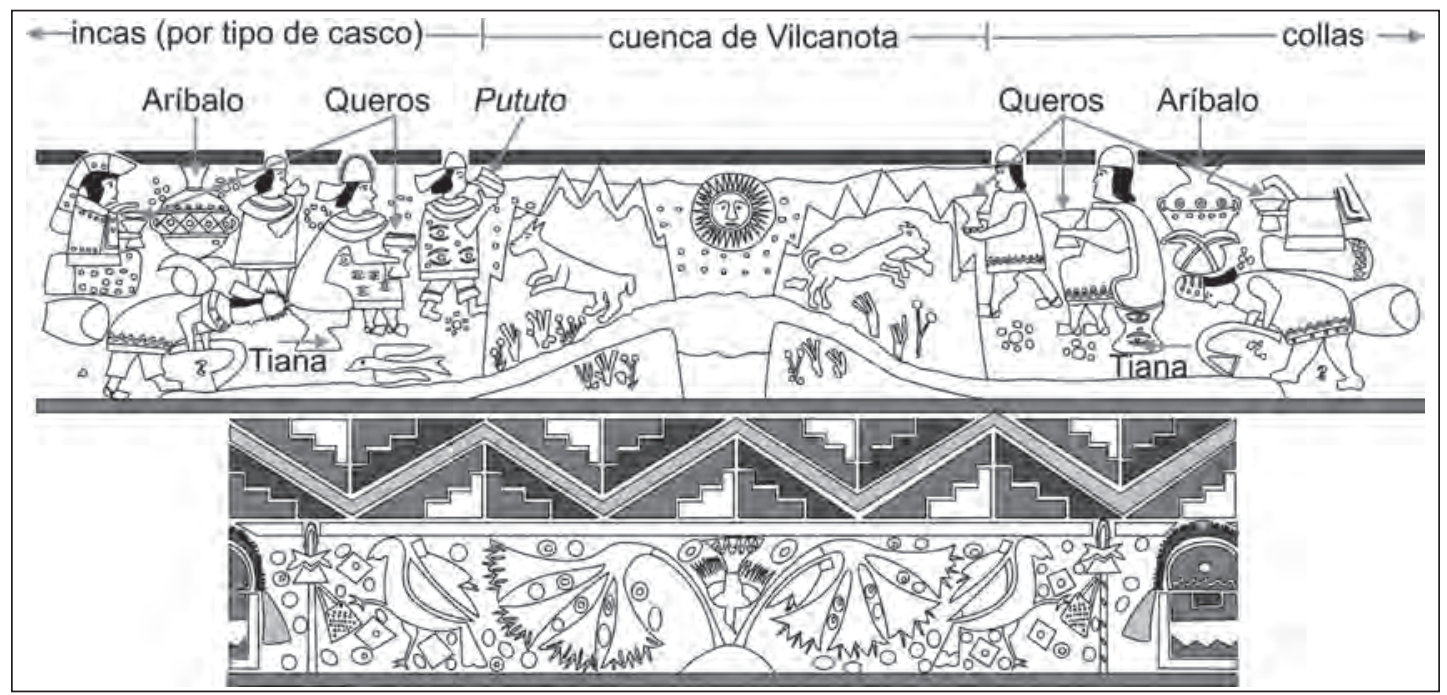

Figura 5. Escena «Encuentro entre incas y collas» (también conocida como Incari-Collari o Brindis de la fertilidad) en llimpisccaquero colonial (siglo XVII d.C.). Véase la proliferación de diseños antropomorfos, la multiplicidad de sus acciones y la propia auto-etnografía que hace el lenguaje visual de este quero. (Pieza: MAM 7523. Colección: Museo de América de Madrid. Fuente: Proyecto FONDECYT 1090110. Dibujo: C. Yáñez).

\section{LOS QUEROS COMO SOPORTE DE MEMORIA}

Spoken language is not always the best medium for communicating thought.

Elizabeth Hill Boone (Introduction: Writing and Recording Knowledge, 1994: 10)

En la época incaica, los queros estuvieron ligados a la imágenes incisas o pintadas ${ }^{15}$ que ellos soportaban (para los casos de madera: tocapus, ir a Figs. 4a y 6) puesto que, tanto el objeto material -vaso de palo- como los significantes visuales ahí plasmados (abstractos lineales), conformaban un mismo conjunto simbólico (imagen/objeto) que permitía materializar, a través de los llamados «banquetes políticos» (y «a manera de testigo» según Cummins 2004), conceptos religiosos, políticos y visitas entre el estado tahuantinsuyano y las comunidades locales (el mismo Cummins 2007, 2004). En igual

15 Especialmente para las piezas de cerámica. 


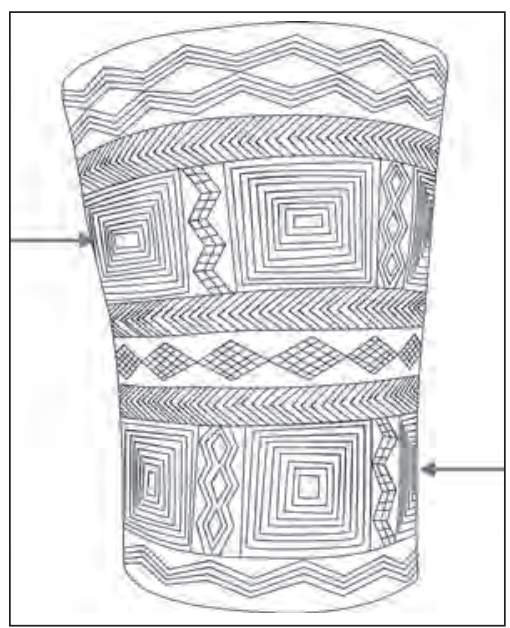

Figura 6. Quero incaico de madera (1470-1533 d.C.) con 2 bandas horizontales de significantes geométricos abstractos lineales incisos (tipo tocapus) continuos sobre fondo de madera natural. (Pieza: MO 122. Colección: Museo Nacional de Arqueología, Antropología e Historia del Perú. Fuente: Proyecto FONDECYT 1090110. Dibujo: C. Yáñez).

sentido (pero ya en la época colonial), los primeros extirpadores de idolatrías (Albornoz $\left[\right.$ ca.1582] ${ }^{16}$ y Ávila $[1598-1608]^{17}$ respectivamente) sostienen haberse percatado que: los vasos para beber que usan los indios eran objetos cargados de memoria (Cummins 2007); por tanto, con una capacidad comunicativa desplegada para funcionar en el «mundo entre los míos» (la «República de Indios»); la cual, prosiguió décadas posteriores.

Por tanto, y de acuerdo con el párrafo anterior, los llimpisccaqueros coloniales -esos «vasos de palo» pintados en bajo relieve con escenas narrativas de trato figurativo (realista y mimético a la naturaleza)- constituyeron un sistema visual de comunicación (tal como se puede visualizar, por ejemplo, en las Figs. 1, 4c y 5). De modo tal que, al decir de algunos investigadores como Flores Ochoa et al. (1998), estas escenas funcionaron como «crónicas visuales»; esto es: significantes mnemotécnicos que permitían recordar un relato mayor; preservando así, un conocimiento del pasado (mitos antiguos, episodios del pasado inca, etc.) -un «hecho de memoria» según Martínez Cereceda (2011 y 2008ms, cf. más adelante)-. Algo similar a lo que sostiene Margarita Gentile (1998) quien postula que, algunos de estos queros coloniales estarían expresando «acontecimientos históricos» -a modo de una base de datos sobre el pasado inca-. En una postura análoga pero apoyada por el uso de otros sistemas de soportes (bailes, arte rupestre, por ejemplo) Martínez Cereceda (2011 y 2008ms) sostiene que, dichas composiciones figurativas (las escenas narrativas de los queros coloniales) representarían «hechos de memoria» sobre el pasado inca, es decir: una reminiscencia creíble y particular del pasado tahuantinsuyano («de los tiempos del inca») que evocaba, en especial, las gestas épicas de algunos gobernantes Incas, guerreros y batallas, a saber: la «Guerra incas contra chancas (Fig. 7) ${ }^{18}$, el «Encuentro entre incas y collas (ver Figs. 4c y 5)»y «Baile de chunchos» ${ }^{19}$ (regresar a Fig. 1), entre los más representativos.

Paralelamente a estas enunciaciones sobre el pasado tawantinsuyano (los «hechos de memoria»), los queros coloniales también contienen representaciones -opiniones- desde la reciente y, para ellos, curiosa realidad colonial; a modo de ejemplo: el impacto de las nuevas tecnologías de transporte -la monta a caballo-, ganaderas -la arriería-, agrícolas -arado de bueyes- y panificadoras (Fig. 8). Así debido al «patrón de repetición» ${ }^{20}$ propio en la iconografía de los llimpisccaqueros, Cummins (1988) agrupa las escenas narrativas y figurativas de los queros coloniales polícromos en 8 categorías (o temas), a saber: 1) tocapu/figurativo 2) motivo arco iris, 3) batalla (regresar a Fig. 7), 4) pareja Inca/Coya (Fig. 9), 5) tocapu, 6) agrícola -compuesto por escenas de siembra, cosecha y transporte de productos -, 7) baile

16 En Duviols 1968.

17 Ritos y Tradiciones de Huarochirí (Gerald Taylor ed. 1987).

18 Gesta épica del joven príncipe Pachacuti Inca Yupanqui quien logra resistir la invasión -al Cuzco- del señorío vecino de los chancas para luego, vencerlos y rechazarlos fuera de la capital imperial. Evento que marca el nuevo orden político, social, económico y religioso del naciente estado incaico.

19 También conocido como tinkuy («batallas rituales») o encuentro entre «incas y chunchos»: comunión ritualizada -por medio de brindis- entre dos mitades (Cummins 2004).

20 Lógica combinatoria por la cual, toda la imaginería de los queros coloniales (llimpisccaqueros) se repite de manera sistemática y estandarizada provocando con ello: motivos y escenas redundantes. 


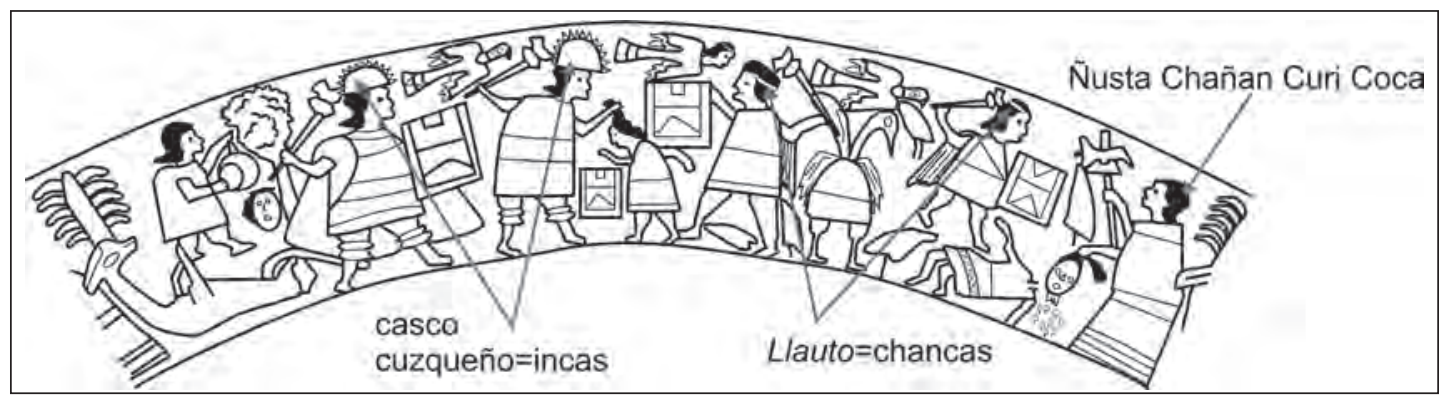

Figura 7. Los queros como soporte de memoria. Escena narrativa, figurativa y mimética que representa un "hecho de memoria», a saber: ciclo mítico "Guerra incas contra chancas». Épica que origina, explica y justifica la formación del Tahuantinsuyo. (pieza: MOMAC 3896. Colección: Museo Inka de la UNSAAC. Fuente: Proyecto FONDECYT 1090110. Dibujo: C. Yáñez). Escena sobre fondo de madera natural.

(ir a Figs. 1 y 8) selva. Siguiendo esta lógica combinatoria una misma pieza de madera puede llegar a tener sobre su superficie, para lograr una mayor efectividad visual y discursiva, dos o más temas de los definidos por Cummins -secuencias narrativas diferentes-e incluso repetidas (de nuevo Fig. 9).

Por tanto y a partir de lo reseñado hasta aquí, queda claro que la letra (littěra) no fue la única materialidad -en tiempos coloniales- con la capacidad de enunciar diferentes tipos de discursividades ya que también los queros, un sistema de soporte de origen nativo y con lenguaje visual, sirvieron para registrar la memoria andina colonial (con temas referentes sobre el pasado tahuantinsuyano) y las actividades desde el presente colonial (escenas de arriería, ganadería, arado con bueyes, panadería etc.). Con esta cualidad comunicativa, los llimpisccaqueros y su lenguaje visual ahí expuesto fueron materialidades con una fuerte carga discursiva dirigida para, y entendida por, las sociedades andinas coloniales (especialmente para las élites nativas). Enunciaciones visuales indígenas que no se hallaban hegemonizadas (no totalmente) por el poder eclesial y civil hispano; y que funcionaron -las imágenes graficas ahí expuestas- como textos y documentos (Fig. 10).

\section{¿Dónde buscar? Al margen de la letra...tAmbién Se comunica}

The official cultural map, of course, be criticized and resisted by those relegated to its margin. William Sewell (The Concept(s) of Culture, 1999: 56)

La «ciudad letrada» hispanoamericana no estuvo omnipresente en toda la realidad nativa, habiendo espacios -intersticios- que operaron al margen de la letra; es decir: lugares donde se continuaron con los modos de registro precolombinos «como si no hubiese habido conquista» según Cummins (2004: 226). En efecto, y alentados por la propuesta de William Sewell (1999: 56), ingresaremos al interior de estos espacios marginales para hallar -precisamente- las manifestaciones artísticas locales donde las sociedades andinas coloniales pudieron plasmar sus propias discursividades insubordinadas por el poder colonial hispano; algunas de las cuales -cabe decir-, resistieron y contradijeron incluso lo dicho por el mapa cultural oficial colonial (por la «ciudad letrada» hispanoamericana).

Es sabido que el Tahuantinsuyo poseyó una «cultura gráfica» ${ }^{21}$ donde las imágenes y su respectivo lenguaje icónico constituyeron uno de los modos de comunicación más populares del imperio (en que «el pincel era la pluma» siguiendo a León-Portilla (1961) o a modo del «art and writing» propuesto -como ya lo hemos mencionado- por Elizabeth Hill Boone (1994)).Sin embargo debido a que las prácticas comunicacionales entre las sociedades andinas coloniales y la «ciudad letrada» hispanoamericana

21 Sin registros escritos alfabéticos pero con prácticas visuales, de oralidad y teatralidades (Chartier 2005). 


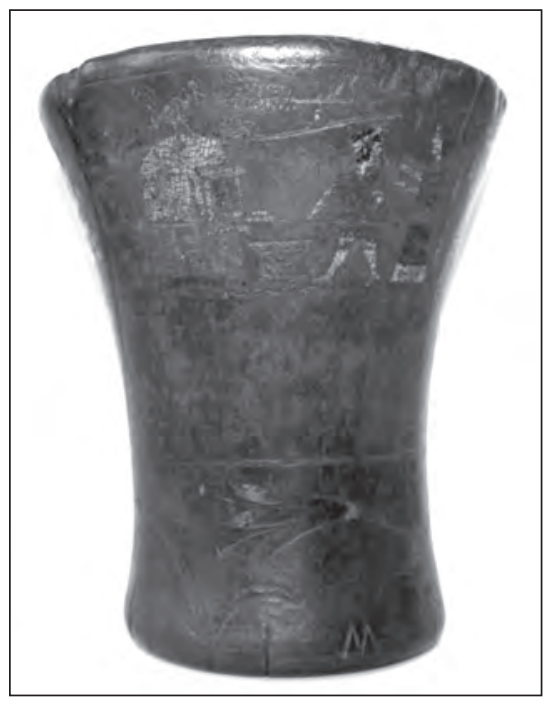

Figura 8. Llimpisccaquero representando las nuevas y curiosas técnicas llegadas a los Andes de los siglos XVI al XVIII, a raíz de la colonización española: «escena de panadería» (siglo XVIII. Pieza MALI IV-2.3-0023, colección Museo de Arte de Lima (MALI), fuente Proyecto FONDECYT 1090110).

fueron heterogéneas, el poder virreinal impulsó -con intenciones de uniformizar y dominar las formas de registro y comunicación indígenas- la difusión de nuevos sistemas de obtención y almacenamiento de información (ajenos y con hermenéuticas diferentes a la experticia andina); los cuales: se basaban en la dicotomía logocéntrica ${ }^{22}$ y eurocéntrica interesada en un conocimiento aprendido en torno a la lectura y escritura alfabética. Sin embargo en el mundo andino colonial, y en concordancia con las posturas de Chartier (2005), la cultura escrita alfabética no redujo -en absoluto- la importancia de otros sistemas de soporte nativos de saber, memoria y persuasión: 1) la imagen y 2) la oralidad.

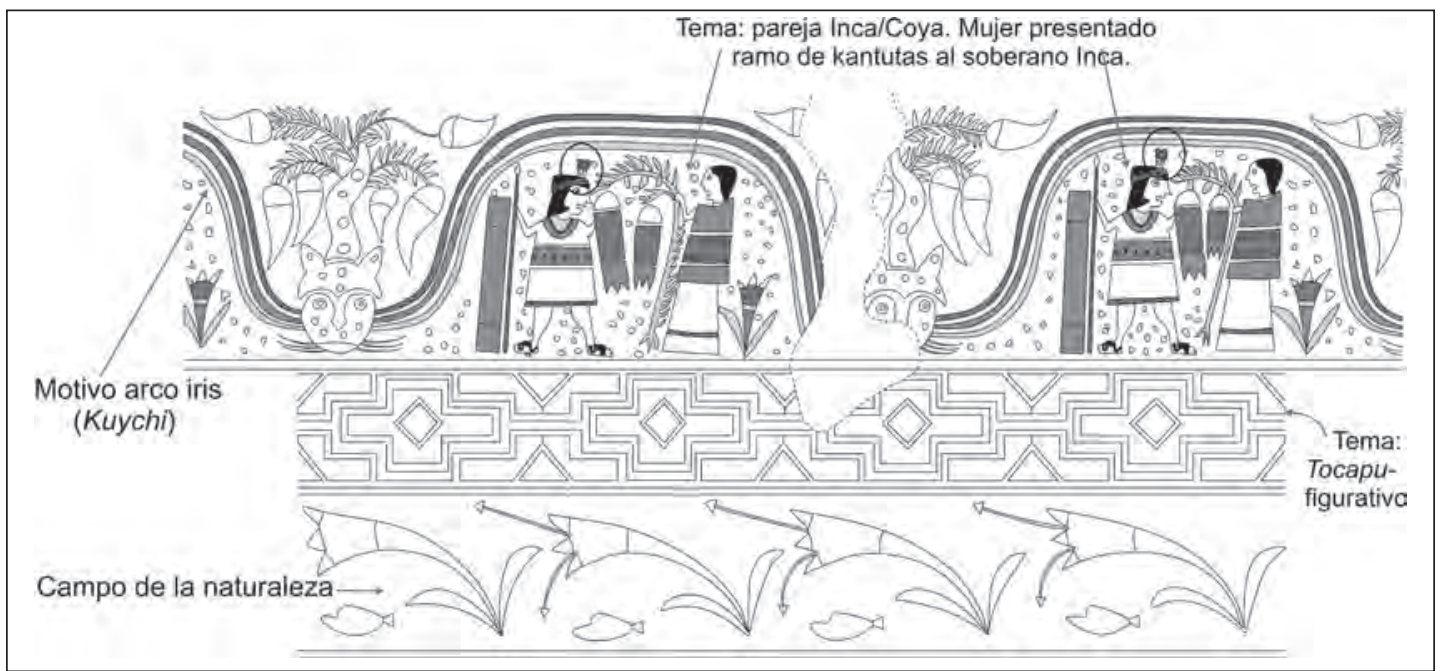

Figura 9. Lógica combinatoria en llimpisccaquero del siglo XVI d.C. tardío: hasta 3 temas -secuencias discursivas- distintas de aquellas definidas por Thomas Cummins (1988). Fíjese además en la ubicación de la mascapaycha debajo del kuychi (construyendo así una alegoría colonial del poder inca). Pieza MoMac 247, colección Museo Inka de la UNSAAC, fuente Proyecto FONDECYT 1090110, dibujo $C$. Yáñez, colores referenciales sobre fondo de madera natural.

Entonces a raíz de esta vigencia colonial postulamos que, las materialidades indígenas de origen precolombino con lenguajes diferentes a la escritura alfabética (como el icónico visual que aparece en los queros -los llamados «etno-soportes»-); constituyen el testimonio nativo fundamental para «pasar al otro lado del espejo» y obtener así, las (sub)versiones andinas del encuentro/choque con las fuerzas hispanas (de «la Conquista» según la historiografía eurocéntrica).

22 Base binaria del saber «científico» occidental que se caracteriza en, situar todas las formas del pensamiento y conocimiento en el texto/escritura y la palabra/lectura, siendo éstas -como prácticas discursivas diferentes- las dos únicas categorías privilegiadas para llegar al conocimiento (Derrida 1989). 


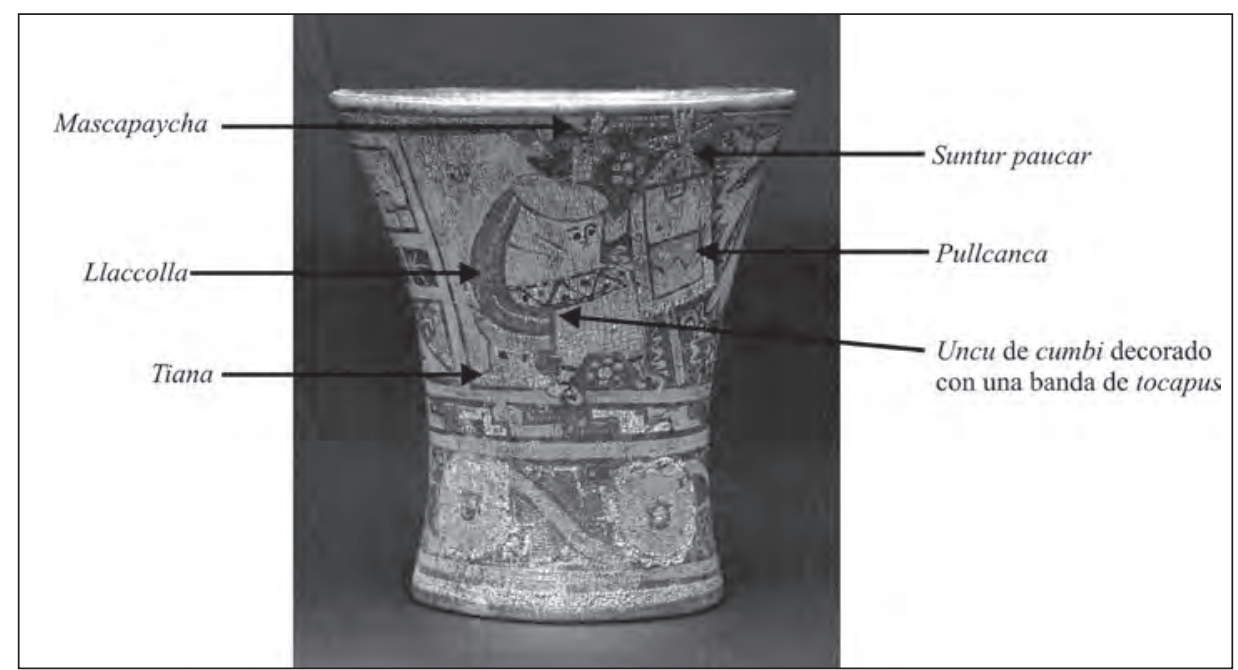

Figura 10. Llimpisccaquero colonial (siglo XVII d.C.) donde su lenguaje visual está funcionando como documento (art and writing): la construcción colonial de la figura y emblemas imperiales del Sapa Inca. Ejemplar mostrando -al «mundo de los míos»- los atributos reales del poder del gobernante (pieza MOMAC, colección Museo Inka de la UNSAAC, fuente Flores Ochoa et al. (1998): 115).

A partir de lo expuesto queda claro que, los queros coloniales polícromos (llimpisccaqueros) fueron «a graphic system that keeps and coveys knowledge (Boone 1994: 3)» donde, a través de las relaciones e interconexiones entre sus significantes (la sintaxis simbólica), las escenas narrativas y figurativas pintadas sobre las superficies de estos «vasos de palo» significaban -comunicaban- a las sociedades andinas coloniales (en especial: a las élites estatales y regionales), a modo de un sistema visual de escritura («a nonverbal system» según la misma Elizabeth Hill Boone 1994) ${ }^{23}$. Entonces «esta antigua manera de escribir historia, sobre la base de pintura» (León-Portilla 1961: XIX) ofrece, entre otras cosas, datos valiosísimos para aproximarnos a la reacción andina colonial ante el impacto pictórico europeo-cristiano acaecido desde el siglo XVI d.C. en adelante. De este modo y siguiendo a Clifford Geertz (1994) acerca de abandonar la «visión intra-estética» del arte, estamos conscientes de que analizando los rasgos formales de este «arte de curacas» puesto en los llimpisccqueros coloniales, podemos aproximarnos a las libertades iconográficas que tuvieron las sociedades andinas coloniales (en especial los indios doctos ${ }^{24}$ y querocamayocs ${ }^{25}$ para reconfigurar sus «vaso de palo» y seguir así con su vena comunicativa y memoriosa de este sistema de soporte. Entonces, y luego de haber reconocido los beneficios de la visualidad de los llimpisccaqueros coloniales: ¿por qué continuar pensando que escribir (comunicar a través de formas visibles) es una cualidad única de la escritura alfabética?, ¿por qué seguir utilizando el logocentrismo de Derrida (1989)?, es decir: entender la escritura según las pautas del Viejo Mundo «as the communication of relatively specific ideas in a conventional manner by means of permanent visible marks» ${ }^{26}$.

23 Revísese por ejemplo Figs. 4c y 5 donde, como parte de la escena «Encuentro entre incas y collas», el lenguaje visual de este llimpisccaquero hace referencia mito-histórica a la invitación del rey qolla al Sapa Inca para brindar en la cuenca del río Vilcanota (Flores Ochoa et al. 1998).

24 Indígenas familiarizados con la mitología clásica europea y el humanismo rescatado por el Renacimiento.

25 Artesanos nativos especializados en los trabajos de madera considerados como bienes suntuarios de uso exclusivo del Sapa Inca y la aristocracia local, como lo fueron: los «vasos de palo» usados para brindar con el dios Sol (Inti; ir a Fig. 11).

26 Elizabeth Hill Boone 1994: 15. 
Antes de penetrar en el lenguaje visual expuesto en los llimpisccaqueros, una premisa de orden. Para el presente ensayo, consideramos las escenas narrativas figurativas puestas en estos «vasos de palo» pintados como "a picture writing» ${ }^{27}$ : un lenguaje gráfico-visible donde sus expresiones pictográficas fueron diseñadas para comunicar significados y relatos teniendo en cuenta, su combinación cromática y posición formal relativa al interior de todo el espacio desplegado (Cummins 1994). Entonces un sistema de soporte que significaba a través de sus representaciones gráficas. Sin embargo a diferencia de las rígidas reglas de la escritura alfabética (aquellas que pretenden igualarse al habla), no todos los miembros de las comunidades andinas poseían las mismas habilidades para interpretar-decodificar la sintaxis simbólica ahí expuesta (leer)- las escenas figurativas pintadas en los llimpisccqueros ya que éstas sólo eran comprendidas, en todos sus niveles de significación y lectura (aquellos de índole político, ceremonial y reciprocidad comunal), sólo por algunos pocos especialistas calificados, competentes e informados (como los indios doctos y demás miembros de la nobleza inca descendiente por ejemplo), con lo cual -valga señalar- dicha lectura les otorgaba legitimidad social. En efecto, las escenas de los queros polícromos no tuvieron un solo sentido similar y global para todos los miembros de la comunidad sino varios distintos; los cuales eran entendidos, en todos sus niveles de significación, sólo por los poseedores de los «serious spreech acts», a saber: aquellos quienes compartían un fondo común de índole estatal como los miembros de la nobleza incaica descendiente y demás curacas locales (Fig. 11).

En consecuencia, el quero fue un soporte nativo discursivo que visualizó, principalmente, enunciaciones y aspiraciones de las élites (soportando por tanto un «arte de curacas»); las cuales, sin embargo, no eran compartidas -por igual- por todos los miembros de las comunidades andinas coloniales. Razón más que suficiente para que algunos investigadores (revisar Boone 1994) no consideren, al sistema comunicativo de los queros (el «picture writing»), como «a real writing» (de base alfabética y logocéntrica).

\section{«SimulaCROS ${ }^{28}$ VISUALES: UN EJEMPLO DE LA AGENCIA ICONOGRÁFICA ANDINA COLONIAL}

El período colonial andino fue -desde un punto de vista pictórico- una disputa semiótica, un intercambio epistemológico en la manera de percibir lo propio de la imagen; a razón que, tanto las fuerzas hispanas como las sociedades andinas del siglo XVI d.C. (entre ellas la incaica) manejaron respectivamente distintos conceptos y lógicas de representación pictórica, entre los más representativos pero sin ánimos de reduccionismos: 1) la mimesis e imagen descriptiva figurativa europea renacentista contra 2) la abstracción geométrica lineal incaica (cf. nota 14) de significado semasiográfico convencional, esto es: significantes visuales que no registran la totalidad del habla, no llegan a igualarla, sino transmiten ideas, conceptos y discursos consensualmente aceptados por aquellos quienes están insertos en su lógica representacional (revisar González y Bray 2008, Salomon 2001, Boone 1994). Por lo tanto, y a diferencia de la pintura española a caballete y pincel del Cinquecento que ilustraba un guión textual conocido por su público observador (la mentada pintasca, cf. nota 9), las imágenes incaicas así como otras de la misma tradición representacional andina no estuvieron exentas -para alcanzar todos sus niveles de significación y lectura- de su interpretación oral hecha por pocos especialistas nativos calificados, competentes e informados en las artes visuales incaicas (como los indios doctos).

Por otro lado la invasión europea introdujo -a «las Indias»- un nuevo repertorio iconográfico y simbólico disímil a su par sudamericano; el cual provenía, dentro de su enormidad y variedad iconográfica, de diversas fuentes plásticas y artísticas (según Lizárraga 2010 y Gisbert 2003) como aquellas de la tradición artística greco-romana (compuesta principalmente por significantes visuales tipo si-

27 Elizabeth Hill Boone 1994: 6.

28 Cummins 1998b. 


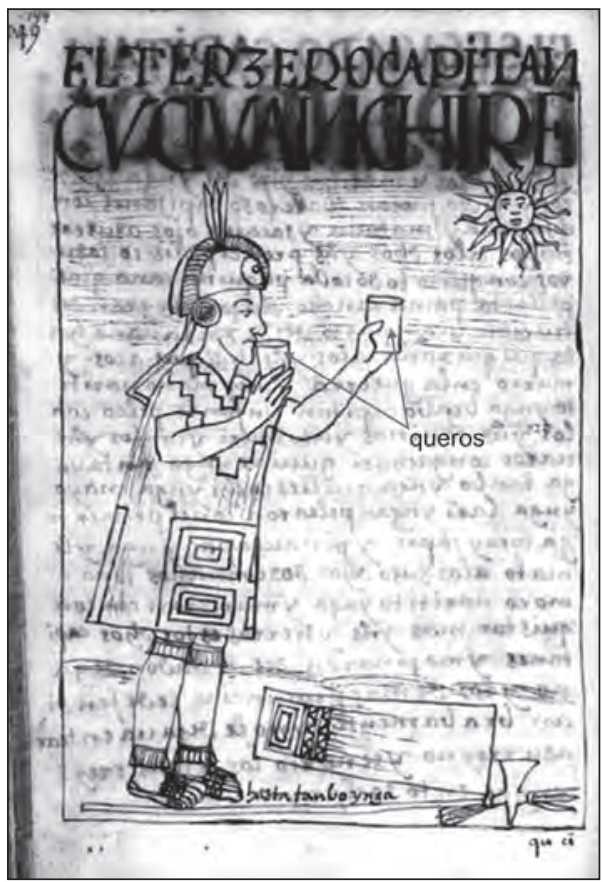

Figura 11. Dibujo «EL TERZERO CAPITÁN, CVCI VAN[AN] CHIRE» (folio [149] 149) de Guaman Poma de Ayala (en 1615) que muestra, el uso nobiliario y exclusivo de los vasos tipo quero (como emblemas imperiales y marcadores de status social). Brindis entre el tercer capitán y la divinidad solar (Inti).

renas, centauros, dragones, basiliscos entre otros) muy difundida en las artes renacentista y manierista europeas de la época (Flores Ochoa et al.1998). Por tanto y a raíz de este choque epistemológico entre la imagen europea renacentista y andina incaica (cada una de las cuales, iba acompañada de sus respectivos repertorios e imaginarios iconográficos), tanto los grupos hispanos como las sociedades andinas coloniales realizaron procesos bilaterales de: captura $\rightarrow$ apropiación $\rightarrow$ transformación y (re) inscripción de cada uno de los significantes visuales exógenos (europeos o andinos) a sus respectivas tradiciones artísticas (Lizárraga 2010, Patricio Cisterna, comunicación personal, 2008).

En consecuencia de ello tenemos llimpisccaqueros coloniales con escenas figurativas que incluyeron, como parte de su reciente universo figurativo nativo -«escenario estético»-, muchos de los seres y emblemas representados y difundidos por las artes renacentista y manierista europeas contemporaneas, en especial: las criaturas del imaginario clásico de reproducción renacentista como centauros, sirenas, basiliscos, dragones y demás seres fabulosos reunidos en «El Fisiólogo: Bestiario Medieval»; los cuales, ya se encontraban operando como parte de su nuevo sistema de vida a raíz de su presencia dentro de desfiles y exequias oficiales (tal como fue el caso de la Tarasca (Fig. 12), por ejemplo).

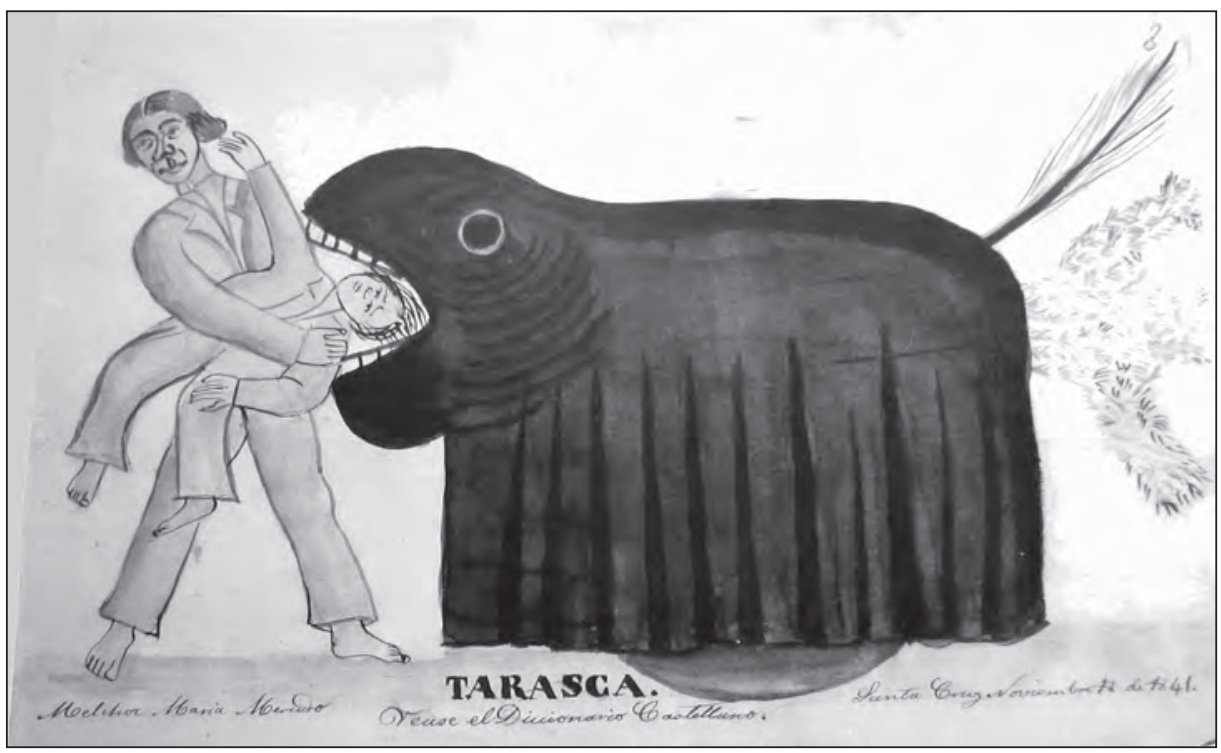

Figura 12. Tarasca visualizada por los «ojos indígenas» en desfiles populares. Criatura según el pintor, naturalista, explorador y músico boliviano Melchor María Mercado (acuarela tomada de su «Álbum de paisajes, tipos humanos $y$ costumbres de Bolivia 1841-1869»). 
Del mismo modo, y continuando con el análisis iconográfico de los significantes dibujados en los queros coloniales tipo llimpisccaquero, se reportó comportamientos -de sus artesanos indígenas ante las prácticas figurativas impositivas hispanas- muchos más activos (como sujetos libres y pensantes) de los que se pensaba si nos basamos únicamente en las fuentes escriturales. Así por ejemplo, la apropiación andina colonial de los seres del imaginario ${ }^{29}$ clásico y renacentista (aquellas reunidas en «El Fisiólogo») no puede ser reducida a un mero asunto de imitación exacta o (mala) copia del vero ícono anclado en la Europa mediterránea ni de su «paráfrasis» ${ }^{30}$ renacentista sino más bien, a «simulacros» visuales (Cummins 1998b); es decir: imágenes indígenas agenciadas que no se redujeron ni ajustaron al mismo modelo estético europeo ya que fueron el resultado de una (re)inscripción andina colonial que produjo sus propias (re)creaciones y (re)producciones pictóricas contemporáneas. A modo de ejemplo: las «sirenas andinas» que, aparte de estar incluidas dentro de un espacio simbólico diferente a los sucedidos en los mundos clásico, medieval y renacentista europeo (como estar dibujadas -aquí en los Andes coloniales- debajo del arco iris -kuychi- y encontrarse además acompañadas por un ave selvático tipo papagayo/loro), se distanciaron de su propio modelo estético europeo (de «El Fisiólogo: Bestiario Medieval») por ser significantes visuales con dos colas y estar sosteniendo, entre sus manos, instrumentos musicales propios de los Andes (como el charango) además de guirnaldas de flores (posiblemente planta de ajíes). También presentan, como un rasgo de indianidad ${ }^{31}$, un cintillo de flores sobre la frente de su cabeza (Fig. 13; Flores Ochoa et al. 1997).

Por tanto, no estamos ante una simple recepción pasiva ni copista por parte de los querocamayocs coloniales sino, todo lo contrario, a una captura agenciada (una que no se ajustó completamente al registro formal ni contenido europeo, permitiéndose cierta libertad iconográfica para «salirse del modelo»). Esta agencia iconográfica otorgó un sentido propio -de «lecturas andinas»- a estos significantes exóticos y desarraigados de la tradición pictórica andina; tales como: reinscribir sobre ellos, sus propios contenidos mitológicos andinos de raíces prehispánicas (tal como sucedió, por ejemplo, con la divinidad andina conocida como Amaru ${ }^{32}$; la cual adquirió -con el propósito de seguir circulado durante el siglo XVII d.C.- un aspecto dragontino (Fig. 15) o de tipo basilisco (Fig. 16; Lizárraga 2010)).

29 Siguiendo a Gilbert Durand (2004), esto es: conjunto de imágenes interrelacionadas entre sí que constituyen parte del pensamiento social (a modo de un Homo Simbolicus).

30 Entendida aquí como el filtro figurativo (según los cánones visuales de la época) hecho a raíz de la reutilización de dichos significantes. Traducción figurativa posible, a razón de que los europeos del Quattrocento como Cinquecento tuvieron acceso y conocimiento de los monumentos, obras o textos originales (del vero ícono).

31 Al igual que la «Virgen del Rosario de Pomata» (cuadro Anónimo del siglo XVII, en Catálogo del Museo Nacional de Arte Boliviano 2005: 105).

32 Al decir del «LEXICON o Vocabulario de la Lengua General del Perú [1560]» de Fray Domingo de Santo Tomás, Amaru es «serpiente generalmente» que se asemeja al dragón (1951 [1560]: 114, 209 y 233). Muy similar a la definición dada años después por González Holguín quien, en 1608, menciona «Dragon [sic]: Amaro, Serpiente grande sin alas» (1952 [1608]: 24 y 669; ver nuestra Fig. 14). En igual sentido de semejanza, Garcilaso describe (1995 [1609]: 234) a las «culebras grandes» como: «llamadas amaru: son mucho más gruesas que el muslo de un hombre y largas de 25 y 30 pies, otras hay menores; todas las adoran aquellos indios, por su grandeza y monstruosidad. Son bobas y no hacen mal. Dicen que una maga las encantó para que no hiciesen mal y que antes eran ferocísimas». Al decir de Cristóbal de Albornoz (en Duviols 1968), la culebra llamada Amaru era mochada con gran reverencia (especialmente entre los habitantes del Antisuyo -la selva-). Observación también compartida por Guaman Poma (1980 [1615]) quien, asegura haber visto a los indios adorar «ídolos» en forma de serpiente o Amaru. Según Fernández (2005: 98-99), el Amaru era un dios que participa en los 3 mundos (hanan pacha o mundo de arriba, kay pacha o mundo de aquí y urun pacha o mundo de abajo) y por tanto, fue una divinidad importante en la mitología y religión andina pues se encontraba asociado además: al sol y la luna. A pesar de esto, el Amaru fue considerado como un dios menor. 


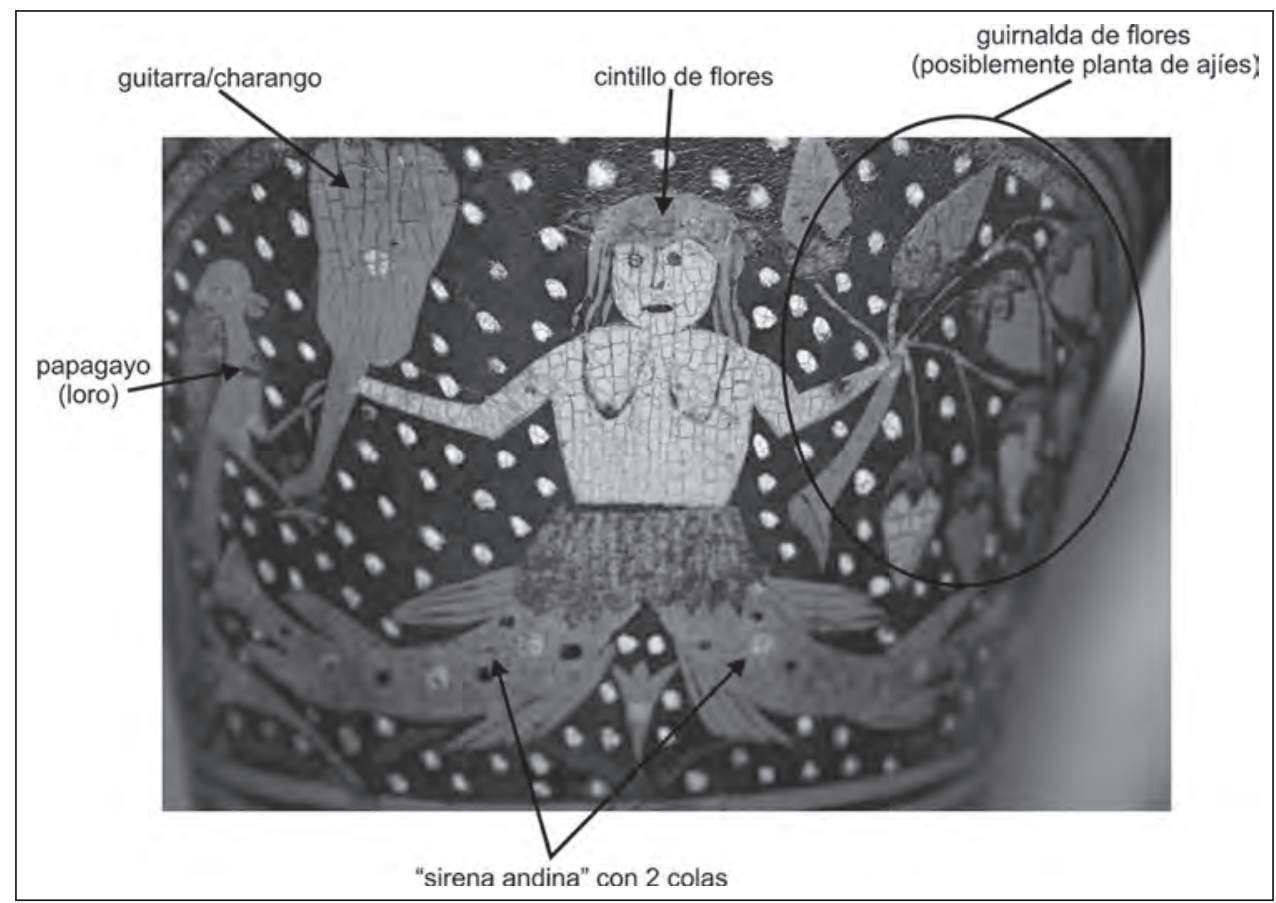

Figura 13. "Simulacros» andinos coloniales: significantes visuales agenciados. Detalle de «sirena andina» basada en diseños estéticos de "El Fisiólogo: Bestiario Medieval» pero que no se ajusta al prototipo mismo pues, "se sale del modelo" con el propósito de agregarle lecturas propias y así dominarla (pieza CFB 3562/MA 49, colección Museo Casa Murillo de la ciudad de La Paz-Bolivia, fuente Proyecto FONDECYT 1090110).

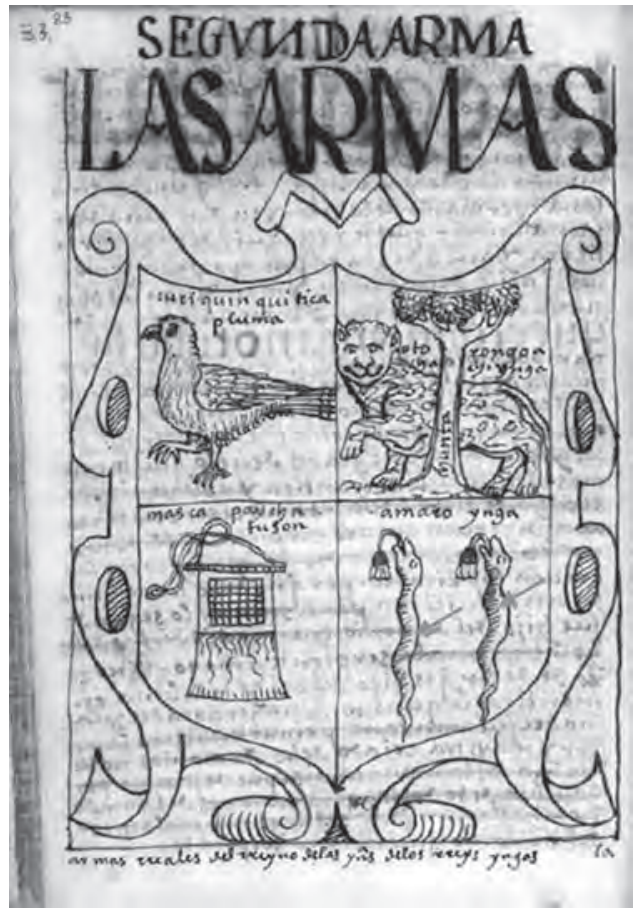

\section{A MODO DE CONCLUSIÓN: LA IMAGEN Y LA VOZ ANDINA COLONIAL}

A partir del presente ensayo queda claro que los «Estudios Andinos Coloniales» necesitan descolonizar sus fuentes (esto es: salir de la hegemonía del registro escrito alfabéticamente). De esta manera, resulta inevitable utilizar los testimonios figurativos como fuentes históricamente válidas pues, como hemos tratado de discutir aquí, el dato iconográfico corresponde a la expresión de comportamientos y opiniones -voces- de una sociedad (para nuestro caso particular: de las sociedades andinas coloniales); pero: ¿qué nos dicen las representaciones figurativas expuestas en los llimpisccaqueros de los siglos XVI al XVIII? Tal como lo hemos señalado en el transcurso de esta investigación, las representaciones pictóricas de estos «vasos de palo» pueden agruparse en discursividades nativas

Figura 14. Amaru de apariencia y estética prehispánica según Guaman Poma de Ayala (1615: folio [83] 83): serpiente tosca y simple dispuesta verticalmente y sin alas. Dibujo como parte del cuartel de «SEGUNDA ARMA DEL YNGA». 


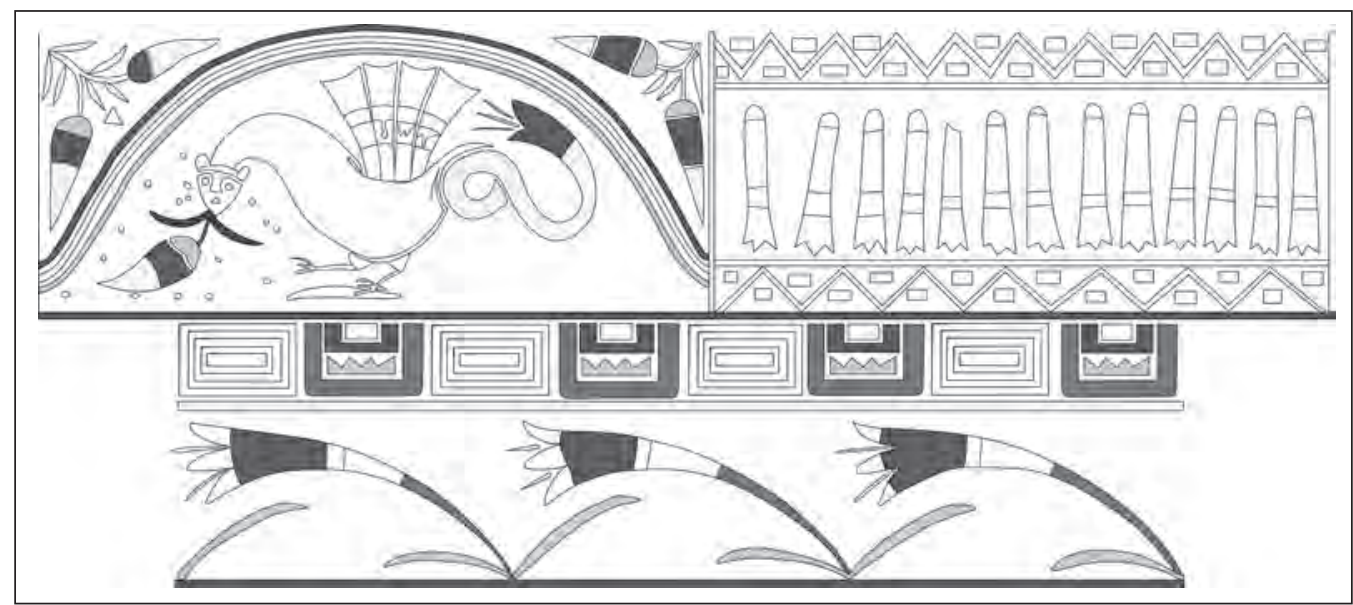

Figura 15. Amaru andino colonial de aspecto dragontino botando flor por su boca. Llimpisccaquero del siglo XVII d.C. (pieza MoMac 168, colección Museo Inka de la UNSAAC, fuente Proyecto FONDECYT 1090110, dibujo: C. Yáñez, colores referenciales sobre fondo pintado de color café).

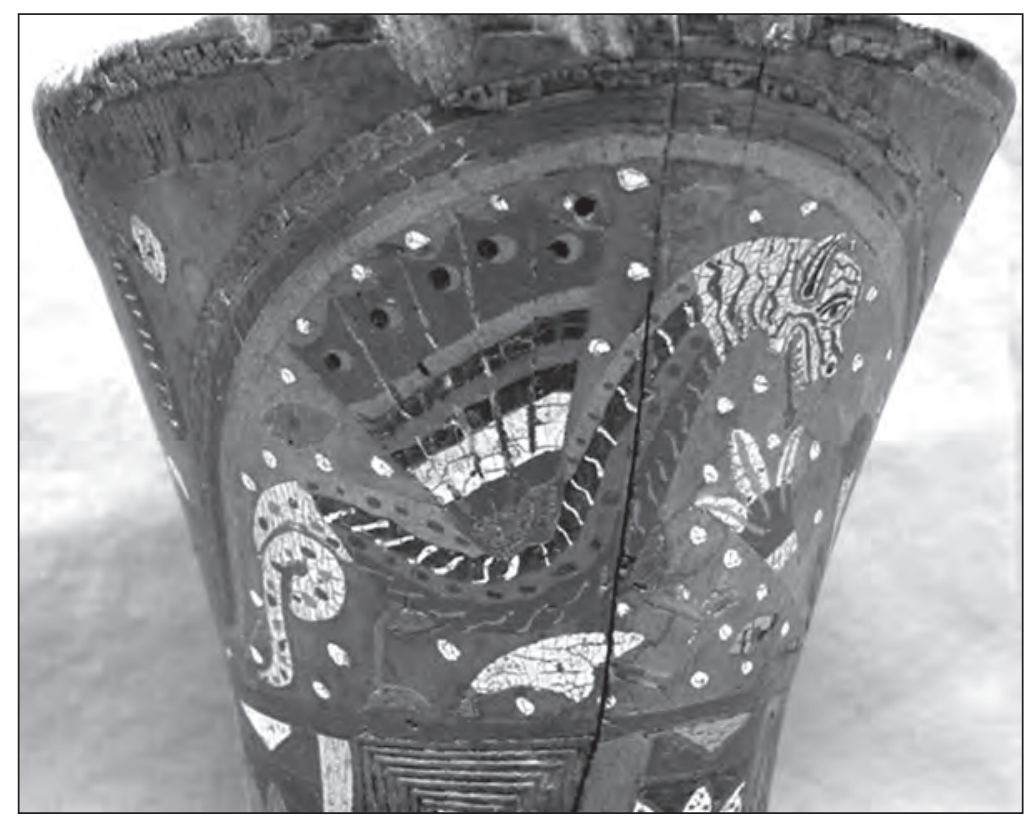

Figura 16. Amaru andino colonial tipo basilisco. Detalle de llimpisccaquero del siglo XVIII d.C. (pieza MO 10395, colección Museo Nacional de Arqueología, Antropología e Historia del Perú, fuente Proyecto FONDECYT 1090110).

sobre dos tópicos generales, a saber: 1) sobre el pasado tahuantinsuyano -los «hechos de memoria» según Martínez Cereceda (2011 y 2008ms)- y, 2) desde la realidad colonial (como escenas de arriería, siembra, arado con yunta de bueyes, bailes, la panadería entre los más representativos).

De este modo resulta convincente asumir que los llimpisccaqueros coloniales fueron, siguiendo su cualidad comunicativa como sistema de soporte de origen prehispánico, materialidades diseñadas para enunciar significados y relatos propios a la «República de Indios». Debido a ello, fueron piezas que 
contuvieron elementos pictóricos -escenas narrativas y figurativas pintadas que funcionaron como un lenguaje icónico (gráfico y visible)- con una fuerte carga informativa de códigos coherentes, y legibles, para las sociedades andinas coloniales insertas en ellos (especialmente las élites gobernantes); siendo por tanto, uno de los principales sistemas de soportes donde quedó plasmada las «voces andinas coloniales» (la «visión de los vencidos» parafraseado a León-Portilla). Así los queros coloniales tipo llimpisccaquero funcionaron como un sistema de comunicación propio a las sociedades andinas; el cual, desarrolló discursos que hablaban más de ellos mismos que de los dominadores (es decir: materialidades no hegemonizadas totalmente por el poder colonial).

En ese sentido, la intención del presente ensayo fue: «desplazar el ojo» del investigador relacionado al período andino colonial e invitarlo a buscar información más allá del texto alfabético ya que los estudios andinos coloniales, no pueden ser reducidos sólo a estas últimas fuentes, es decir: reconocer los registros figurativos como testimonios y fuentes históricamente válidas dejadas por las sociedades indígenas sudamericanas de los siglos XVI al XVIII d.C. Se trata, entonces, de cruzar los límites de la hegemonía de la letra como sistema de expresión y comunicación dominante e incitar a desplazarnos hacia «otros» sistemas comunicativos (los d lenguajes visuales figurativos). De este modo, creemos que los estudios andinos coloniales se acercarían más a un discurso polifónico y multiautoral (esto es: uno que responda a muchas voces y lugares sociales).

Por lo tanto, y luego de haber demostrado las ventajas -para el rescate de las «voces andinas coloniales»- de utilizar los sistemas de soportes de origen precolombino con lenguajes visuales que siguieron circulando, aunque reconfigurados, en el contexto colonial (muchos de ellos, al margen de la letra y de su respectivo leguaje alfabético, tales como: los queros coloniales polícromos tipo llimpisccaquero); queremos estimular, al resto de colegas e investigadores sociales, a conceptualizar el dato iconográfico como una de las tantas maneras que tuvieron las sociedades andinas coloniales para vehicular mensajes y comunicaciones sociales; es decir: utilizar el lenguaje icónico visual como un recurso legítimamente válido para comprender los fenómenos históricos; recordando con ello, los principios fundantes dictados décadas atrás por Aby Warburg (2005 [1912]) y Erwin Panofsky (1976) acerca de que, el estudio iconográfico nos permite revelar las actitudes de fondo -más profundas- de un grupo social. En concordancia con dichas recomendaciones, escribir una «verdadera» o «fidedigna» historia andina colonial basada -únicamente- en las manoseadas fuentes escritas no es la única manera de acceder a las memorias de las sociedades andinas coloniales ya que, como hemos tratado de señalar aquí, la dimensión iconográfica (el lenguaje visual de los queros coloniales tipo llimpisccaquero, por ejemplo) ofrece también informaciones fundamentales para la construcción de la misma.

\section{Agradecimientos}

Esta investigación es la versión corregida y actualizada de un estudio realizado, entre marzo y agosto del 2009, como parte del curso «Teoría de la historia: después del modernismo ¿qué? Nuevas tensiones» (del programa Magíster en Estudios Latinoamericanos, Universidad de Chile). Por tanto deseo agradecer a la Dra. María Elisa Fernández (profesora del mismo) y a todos mis compañeros de clase, por sus sugerencias y observaciones a esta investigación; en especial: a Alejandro Herrera Villagra. Del mismo modo, al Dr. José Luis Martínez Cereceda (investigador responsable del proyecto FONDECYT 1090110) y demás colegas de citado proyecto. At last but not least, a Ana Barrial Acosta por sus diligencias para que este trabajo salga a la luz. 


\section{BiBLIOGRAFÍA}

APPLEBY, Joyce; Lynn HUNT y Margaret JACOB

1999 La verdad de la historia. Barcelona: Editorial Andrés Bello.

BAXANDALL, Michael

2000 Pintura y vida cotidiana en el Renacimiento. Barcelona: Editorial Gustavo Gili.

BERNAL, Martín

1993 Atenea Negra. Las raíces afroasiáticas de la civilización clásica. Barcelona: Editorial Crítica.

BOONE, Elizabeth Hill

1994 «Introduction: Writing and Recording Knowledge». En: W. Mignolo y E. H. Boone (eds.), Writing Without Words: Alternative Literacies in Mesoamerica and the Andes. Durham NC: Duke University Press.

CHARTIER, Roger

2005 El presente del pasado. Escritura de la historia, historia de lo escrito. México: Universidad Iberoamericana, Departamento de Historia.

CORNEJO POLAR, Antonio

2003 Escribir en el aire. Ensayos sobre la heterogeneidad socio-cultural en las literaturas andinas. CELACPLatinoamericana Editores. Lima y Berkeley.

CUMMINS, Thomas

1988 Abstraction to narration: kero imagery of Peru and the colonial alteration of native identity. Ph.D. UCLA Dissertation, 2 vols. U.M.I Dissertation Services. Ann Arbor, Michigan.

1994 «Representation in the 16th Century and the colonial Image of the Inca». En: W. Mignolo y E. H. Boone (eds.), Writing Without Words: Alternative Literacies in Mesoamerica and the Andes. Durham NC: Duke University Press.

1998a «Let me see! Reading Is for Them: Colonial Andean Images and Objects "como es costumbre tener los caciques Señores'». En: E.H. Boone y T. Cummins (eds.) Native Traditions in the Postconquest World. Washington D.C.: Dumbarton Oaks.

$1998 b$ «El lenguaje del arte colonial: Imagen, ékrasis e idolatría». En Primer encuentro internacional de peruanistas. Estado de los estudios histórico sociales sobre el Perú a fines del siglo XX (vol. 2); Lima: Editores Universidad de Lima, UNESCO y Fondo de Cultura Económica.

2004 Brindis con el Inca. La abstracción andina y las imágenes coloniales de los queros. Lima: UNMSM, Universidad Mayor de San Andrés y Embajada de los Estados Unidos de América.

2007 «Queros, Aquillas, Uncus, and Chulpas: The Composition of Inka Artistic Expression and Power». En: R. Burger, C. Craig y R. Matos (eds.) Variations in the expression of Inka Power. Washington D.C.: Dumbarton Oaks.

DERRIDA, Jacques

1989 La escritura y la diferencia. Barcelona: Editorial Anthropos.

DILLEHAY, Tom

2003 «El colonialismo inka, el consumo de chicha y los festines desde una perspectiva de banquetes políticas». Boletín de Arqueología PUCP, Nº 7: 355-363. Lima.

DURAND, Gilbert

2004 Las estructuras antropológicas del imaginario. México: FCE.

DUVIOLS, Pierre

1968 «Un inédito de Cristóbal de Albornoz: La Instrucción para descubrir todas las guacas del Piru y sus camayos y haciendas [ca. 1582]». Journal de la Societé des Americanistes, Vol. 56, № 1: 7-39. Paris.

FERNÁNDEZ, Christian

2004 Inca Garcilaso: Imaginación, memoria e identidad. Lima: UNMSM.

FLORES OCHOA, Jorge; Elizabeth KUON y Roberto SAMANEZ

1997 «Vasos de madera. Región del Lago Titicaca». Arkinka, N² 25: 102-111. Lima.

1998 Qeros. Arte inka en vasos ceremoniales. Lima: BCP.

DE LA VEGA, Garcilaso

1995 Comentarios reales de los Incas [1609] (vols. 1 y 2). Carlos Araníbar (ed.), México: FCE. 
GEERTZ, Clifford

1994 Conocimiento Local. Ensayos sobre la interpretación de las culturas. Barcelona y Buenos Aires: Ediciones Paidós Ibérica.

GENTILE, Margarita

1998 «Rimani, Quellcani, Yuyani. Notas sobre las formas de registro, conservación y uso de datos durante el Tahuantinsuyu». Sequilao. Revista de Historia, Arte y Sociedad, Vol. VII, No 12: 43-63. Lima.

GISBERT, Teresa

2003 «El otro en el Mundo Virreinal». En: A.M. Loradi, C. Salazar-Soler y N. Watchel (eds.) Homenaje a John Murra. Los Andes: cincuenta años después (1953-2003). Lima: PUCP.

GONZÁLEZ CARVAJAL, Paola y Tamara BRAY

2008 «Introducción: Lenguajes Visuales de los Incas». En: P. González Carvajal y T. Bray (eds.) Lenguajes Visuales de los Incas. Oxford: British Archaeological Reports (BAR).

GONZÁLEZ HOLGUÍN, Diego

1952 Vocabulario de la lengua general de todo el Perúllamada Lengua QQuichua o del Inca [1608]. Lima: UNMSM, Instituto de Historia.

GREIMAS, Algirdas Julien

1971 Semántica estructural. Investigación metodológica. Madrid: Editorial Gredos.

GUAMAN POMA DE AYALA, Felipe

1980 Nueva coronica y buen gobierno [1615] (Transcripción, prólogo, notas y cronología de Franklin Pease). Caracas: Biblioteca Ayacucho.

HABERMAS, Jürgen

1989 Discurso Filosófico de la Modernidad. Buenos Aires: Editorial Aguilar/ Taurus.

IWASAKI CAUTI, Fernando

1986 «Las panacas del Cuzco y la pintura incaica». Revista de Indias, N 177: 59-74. Madrid.

JULIEN, Catherine

1999 «History and Art in Translation: The Paños and Other Objects Collected by Francisco de Toledo». Colonial Latin American Review, Vol. 8, № 1: 61-89. Oxfordshire.

KAPLAN, Emily, Ellen PEARLSTEIN, Ellen HOWE y Judith LEVINSON

1999 «Qeros. Análisis técnico de los qeros pintados de los Períodos Inca y Colonial». Íconos. Revista Peruana de Conservación, Arte y Arqueología, № 2: 30-38. Lima.

LEÓN-PORTILLA, Miguel

1961 Visión de los Vencidos. Relaciones indígenas de la conquista. México: UNAM.

LIEBSCHER, Verena

1986 La iconografía de los qeros. Lima: GH. Herrera.

LIZÁRRAGA IBÁÑNEZ, Manuel Antonio

2009 «Las élites andinas coloniales y la materialización de sus memorias particulares en los 'queros de la transición' (vasos de madera del siglo XVI)». Boletín del Museo Chileno de Arte Precolombino, Vol. 14, $\mathrm{N}^{\circ} 1$ : 37-53. Santiago de Chile.

2010 Los queros coloniales y el imaginario clásico y renacentista. Tesis para optar el grado de Magíster en Estudios Latinoamericanos, Centro de Estudios Culturales Latinoamericanos, Facultad de Filosofía y Humanidades de la Universidad de Chile. Santiago de Chile.

MARTÍNEZ CERECEDA, José Luis

2011 «¿Cómo recordar? La construcción de las memorias andinas coloniales (siglos XVI y XVII)». En: L. Regalado de Hurtado y F. Hernández Astete (eds.) Sobre los Incas. Lima: PUCP, Instituto RivaAgüero.

2008 Discursos andinos coloniales, Soportes, confluencias y transformaciones. Propuesta enviada al Concurso Nacional de Proyectos, FONDECYT. Santiago de Chile.

MESA, José de y Teresa GISBERT

1962 Historia de la Pintura Cuzqueña. Buenos Aires: Instituto de Arte Americano e Investigaciones Estéticas. 


\section{MUSEO NACIONAL DE ARTE (MNA)}

2005 Catálogo. Obras Maestras. La Paz: Museo Nacional de Arte.

PANOFSKY, Erwin

1976 Estudios sobre Iconología. Madrid: Alianza Universitaria.

POSNANSKY, Arthur

1945 Tihuanacu: la cuna del hombre americano. New York: J. J. Augustin.

POWELL, Jason y Wahidin AZRINI

2003 «Engaging with Gerontology: Structuralism, Power and Ageing». Sincronia, Fall: 1-10. Disponible en: <http://sincronia.cucsh.udg.mx/powello3.html>, [acceso el 10 de Abril de 2009].

ROBOTHAM, Don

1997 El poscolonialismo: el desafío de las nuevas modernidades. Disponible en: <www.unesco.org/issj/ rics153/robothamspa.html>, [acceso el 24 de marzo de 2009].

ROWE, John $\mathrm{H}$.

1961 «The Chronology of Inca Wooden Cups». En: S. Lothrop (ed.) Essays in Pre-columbian Art and Archaeology. Boston: Harvard University Press.

1976 «El movimiento nacional Inca del siglo XVIII». En: A. Flores Galindo (comp.) Tupac Amaru II-1780. Sociedad colonial y sublevaciones populares. Lima.

2003 Los Incas del Cuzco, siglos XVI - XVII - XVIII. Cusco: INC, Región Cusco.

SALOMON, Frank

1994 «La textualización de la memoria en la América Andina: una perspectiva etnográfica comparada». América Indígena, Vol. 54, º 4: 229-261. México.

2001 «How an Andean »Writing Without Words« Works». Current Anthropology, Vol. 42, N 1: 1-27. Chicago.

SANTO TOMAS, Fray Domingo de

1951 LEXICON, o Vocabulario de la Lengua General del Perú [1560]. Lima: UNMSM.

SEWELL, William

1999 «Concept(s) of Culture». En: V. Bonnell y L. Hunt (eds.) Beyond the cultural history. Berkeley, Los Angeles y Londres: University of California Press.

STASTNY, Francisco

1993 «El arte de la nobleza inca y la identidad andina» En: H. Urbano (comp.) Mito y simbolismo en los Andes. La figura y la palabra. Cusco.

TAYLOR, Gerald (ed.)

1987 Ritos y Tradiciones de Huarochirí: manuscrito quechua de comienzos del siglo XVII. Lima: IEP e IFEA.

WACHTEL, Nathan

1976 Los vencidos. Los indios del Perú frente a la conquista española (1530-1570). Madrid: Alianza Editorial.

WARBURG, Aby

2005 «Arte italiano y astrología internacional en el Palazzo Schifanoia de Ferrara (1912)». En: F. Pereda (ed.) El Renacimiento del paganismo. Aportaciones a la historia cultural del Renacimiento Europeo. Madrid: Alianza Editorial.

WEEKS, Jeffrey

1993 «Foucault y la Historia». En: H. Tarcus (comp.) Disparen sobre Foucault. Buenos Aires: Editorial El Cielo por Asalto.

WÖLFFLIN, Enrique

1961 Conceptos fundamentales en la Historia del Arte. Madrid: Editorial Espasa Calpe.

ZIÓLKOWSKI, Mariusz; Jaroslaw ARABAS e Ian SZEMINSKI.

2008 «La historia en los Queros: Apuntes acerca de la Relación entre las Representaciones Figurativas y los Signos ‘Tocapus'». En: P. González Carvajal, T. Bray (eds.) Lenguajes Visuales de los Incas; Oxford: BAR. 